Historic, archived document

Do not assume content reflects current scientific knowledge, policies, or practices. 



\section{U. S. DEPARTMENT OF AGRICULTURE, BUREAU OF ENTOMOLOGY-BULLETIN NO. 111. \\ L. O. HOWARD, Entomologist and Chief of Bureau.}

\section{THE HOP APHIS IN THE PACIFIC REGION.}

WILLIAM B. PARKER, M. S., Entomological Assistant.

Issued May 6, 1913.

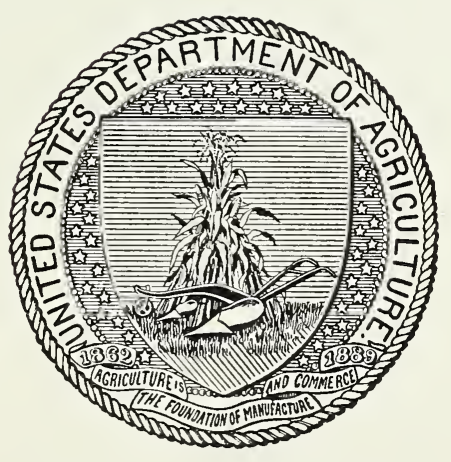

WASHINGTON:

GOVERNMENT PRINTING OFFICE. 1913. 


\section{BUREAU OF ENTOMOLOGY.}

L. O. Howard, Entomologist and Chief of Bureau.

C. L. Marlatt, Entomologist and Acting Chief in Absence of Chicf.

R. S. Clifton, Executive Assistant.

IV. F. TAstet, Chief Clerk.

F. H. Chittenden, in charge of truck crop and stored product insect investigations.

A. D. Hopkins, in charge of forest insect investigations.

W. D. Hunter, in charge of southern field crop insect investigations.

F. M. WEBSTER, in charge of cereal and forage insect investigations.

A. L. Quaintance, in charge of deciduous fruit insect investigations.

E. F. Phillips, in charge of bee culture.

D. M. Rogers, in charge of preventing spread of moths, field work.

Rolla P. CuRRIE, in charge of editorial work.

Mabel Colcord, in charge of library.

Truck Crop and Stored Product Insect Investigations.

F. H. Chittenden, in charge.

C. H. Popenoe, Wh. B. Parker, H. O. Marsh, M. M. High, John E. Graf, Fred

A. Johnston, C. F. Stahl, D. E. Fink, A. B. Duckett, entomological assistants.

I. J. Condit, R. S. VAile, collaborators in California.

IV. N. ORD, collaborator in Oregon.

Thos. H. Jones, collaborator in Porto Rico.

Marion T. Van Horn, Pauline M. Johnson, Anita M. Balinnger, Cecilia Sisco, preparators. 


\section{LETTER OF TRANSIITTAL.}

\section{U. S. Department of Agriculture, Bureau of Entomology, Washington, D. C., December 21, 1912.}

Sin: I have the honor to transmit herewith the manuscript of a paper entitled "The hop aphis in the Pacific region," prepared with admirable thoroughness by Mr. William B. Parker, Entomological Assistant. The topic is one which has engaged Mr. Parker's attention for two seasons, 1911 and 1912. The work covers investigation in the States of Washington, Oregon, and California. The principal work was conducted in California, but the author has had considerable experience with hop insects, including the hop aphis, in British Columbia. The principal insect pests of the hop have not, until recent years, had adequate treatment in publications on economic entomology: and this paper should therefore prove of great value to hop growers.

I recommend its publication as Bulletin No. 111 of this bureau. Respectfully,

Hon. James WiLsox,

L. O. Howard,

Entomologist and Chief of Bureau.

Secretary of Agriculture. 



\section{CONTENTS.}

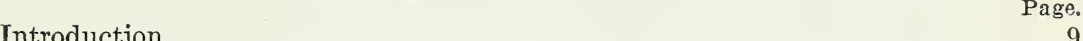

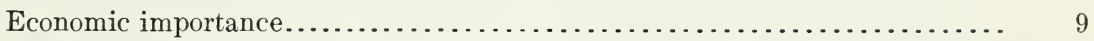

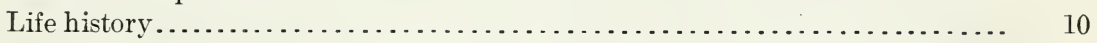

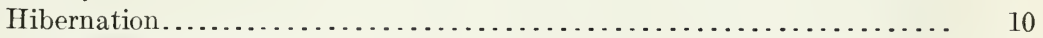

Aphides on hop roots.................................... 10

Emergence from hibernation.............................. 12

Method of reproduction.................................... 12

Number of generations on alternate host...................... 13

Migrating forms........................................... 13

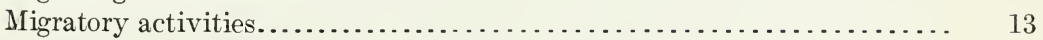

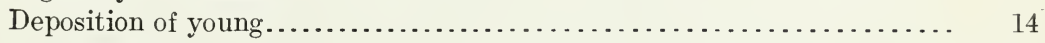

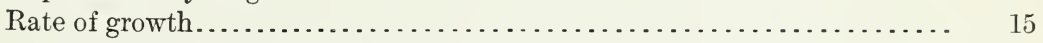

Number of young deposited by viviparous females................. 16

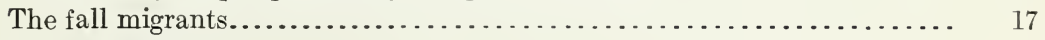

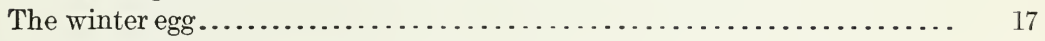

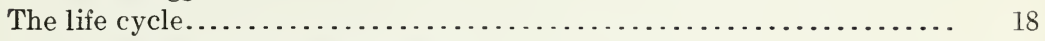

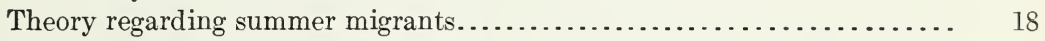

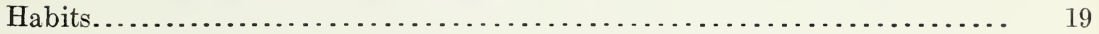

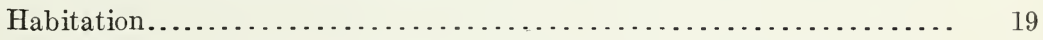

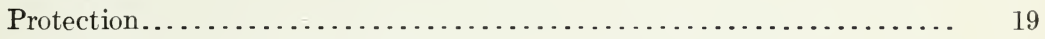

Relation of ants to the hop aphis............................ 19

First appearance of the hop aphis in the season.................. 20

Favorable and unfavorable conditions for the aphis................. 20

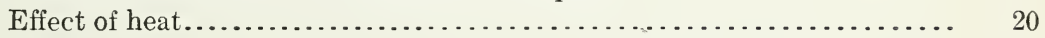

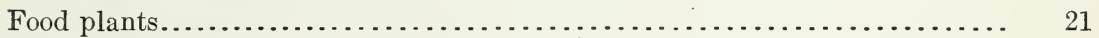

Nature of damage................................................. 21

General effect of aphides upon hops........................... 21

Honeydew and its effect on the hops............................ 22

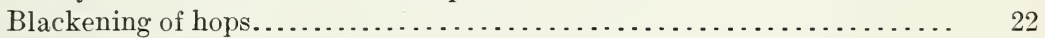

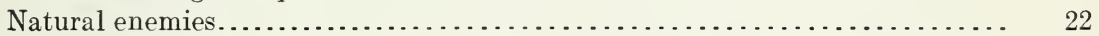

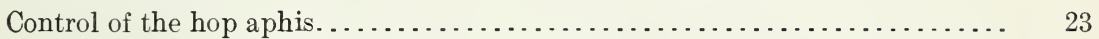

Axioms of successful control................................ 23

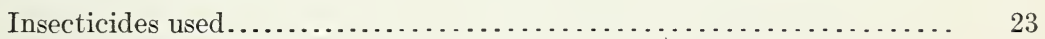

Time to begin spraying...................................... 23

Number of applications.................................... 24

Necessity for early spraying................................ 24

Necessity for thorough work............................... 24

Procrastination................................................... 24

Spraying experiments.............................................. 24

Mixing nicotine solutions and whale-oil soap................. 27

Preparation of the flour paste.............................. 27

Advantages of flour paste over whale-oil soap as a spreader for contact insec-

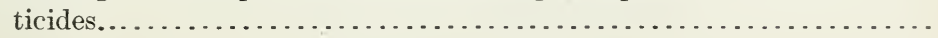


Control of the hop aphis-Continued. Page.

Quassia............................................... 28

Effect of spray materials upon the quality of sprayed hops .......... 30

Direction in which to work.............................. 30

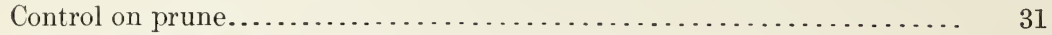

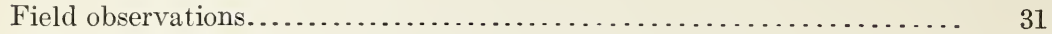

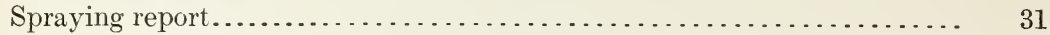

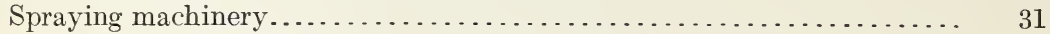

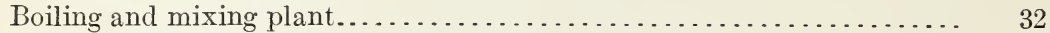

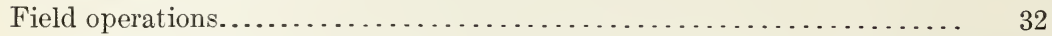

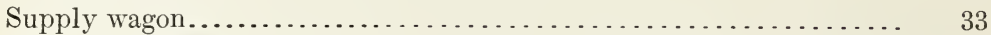

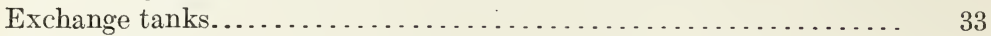

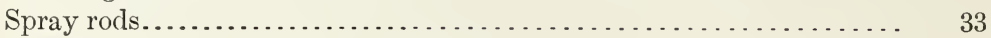

Nozzles......................................... 33

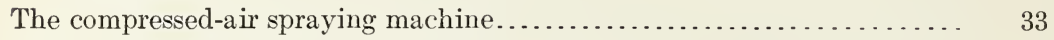

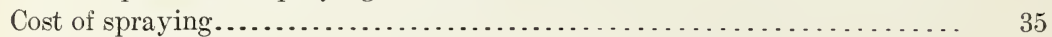

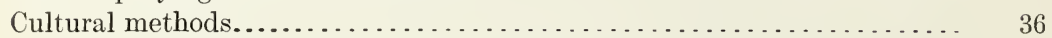

Clean culture.......................................... 36

Stripping the vines................................... 36

Picking off infested leaves............................. 37

Fertilization and irrigation............................... 37

General summary, with recommendations........................ 37

The more important writings on the hop aphis................... 38

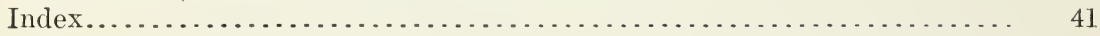




\section{ILLUSTRATIONS.}

PLATES.

Plate I. Fig. 1.-Nymphs and winged forms of the hop aphis (Phorodon humuli) on hop leaves. Fig. 2.-Winter eggs of the hop aphis .....

II. Fig. 1.-Wingless progeny of winged hop aphides from alternate host. Fig. 2.-Willows along edge of hopyard, which were erroneously supposed to harbor hop aphides...................

III. Fig. 1.-Normal hop cones and hop cones injured by the hop aphis. Fig. 2.-Vines severely injured by the hop aphis, showing lack of growth as compared with uninjured vines.................

IV. Fig. 1.-Hopvines severely injured by the hop aphis, and left in the field. Fig. 2.-Enlarged view of damaged and moldy hopvines..

V. Fig. 1.-Eggs of Hippodamia convergens among hop aphides. Fig. 2.-Syrphus fly larvæ feeding upon the hop aphis.............

VI. Fig. 1.-Hindu laborer cooking flour paste. Fig. 2.-Boiling and mixing plant used at Independence, Oreg. . . . . . . . . . . . . . .

VII. Fig. 1.-Hand pump and barrel on sledge. Fig. 2.-Knapsack spray-

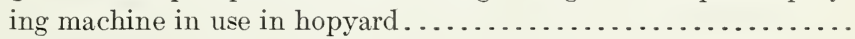

VIII. Fig. 1.-Power outfit on narrow truck, in use in hopyard. Fig. 2.Filling power outfit from improvised supply wagon...........

IX. Fig. 1.-Compressed-air spraying machine, showing air bottle, tank, reducing valve, and pressure gauge. Fig. 2.-Filling air bottles

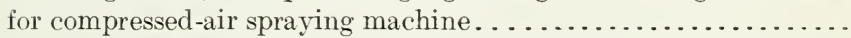

X. Fig. 1.-Hopvine stripped, and tied below the point of stripping, showing free condition of all foliage. Fig. 2.--Hopvine stripped, and tied above the point of stripping, showing matted condition

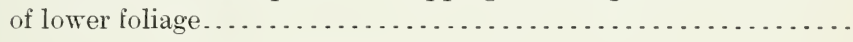

TEXT FIGURES.

Fig. 1. Field cages so placed as to catch any hop aphides that might emerge from eggs deposited upon the hop roots . . . . . . . . . . . . . . . .

2. The hop aphis (Phorodon humuli): Wingless viviparous female . . . . . .

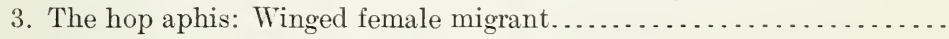

4. Head of the hop aphis, showing frontal tubercles............... 15

5. Head of the melon aphis (Aphis gossypii)................. 15

6. The hop aphis: Nymph, showing wing-pads................ 17

7. Diagram showing relative number of aphides in different parts of a single hopyard, indicating the increased infestation near Santa Rosa

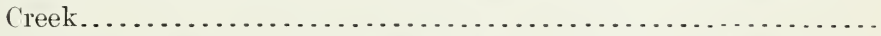

8. Short-pole hopyard, showing dense foliage around base of vines, which

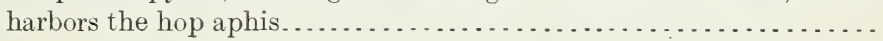





\title{
THE HOP APHIS IN THE PACIFIC REGION.
}

\author{
(Phorodon humuli Schrank.)
}

\section{INTRODUCTION.}

The hop aphis (Phorodon humuli Schrank) was known as a pest in the hop gardens of England and of Continental Europe long before hop growing became an industry in America. In the United States this aphis first appeared in New York in 1863, in Michigan in 1866, and in Wisconsin in 1867, and in these States it seriously injured that crop during the early eighties. It soon reached the Pacific Coast, where it first appeared in 1890, and it is now troublesome in most of the hop-growing sections of British Columbia, Washington, Oregon, and California.

The investigation upon which this paper is based began during the spring of 1911 and was continued through two seasons, being completed in the fall of 1912. Experiments were conducted and practical control work was carried on at Sacramento and Santa Rosa, Cal., and at Independence, Oreg. The recorded efficiency of the various insecticides tested is based upon actual counts of living aphides, made before and after spraying. The data upon the cost of control work and methods employed in field operations are based upon the work at Santa Rosa, Cal., and Independence, Oreg., where the prime object of this investigation was carried out, i. e., the economical control of the aphis of the hop.

Acknowledgments are due to Dr. F. H. Chittenden, in charge of Truck Crop and Stored Product Insect Investigations; to Mr. J. Williamson, of Santa Rosa, Cal., who generously assisted me in some of the experimental work; to Mr. Theo. Eder, superintendent of the E. Clemens Horst Co., who furnished me with a field laboratory and a temporary assistant during the summer; to Mr. R. S. Raven, who ably assisted me in the life-history and experimental work, and to Mr. H. N. Ord, who collected much of the data upon methods and cost of control and who carried out the field work in Oregon.

\section{ECONOMIC IMPORTANCE.}

The hop aphis has probably been present on the Pacific coast since the time hops have been grown there on a large scale. The greatest injuries from this pest occur in Oregon, Washington, and British Columbia, but serious losses are occasionally sustained in California. 
In 1911 the hops at Santa Rosa, Cal., were severely attacked by this aphis. In fact, if the hop crop of the world had not been small and the demand for hops consequently very great, many of the growers in this section would have been unable to dispose of their crops. During the same season the financial loss due to injury by this aphis to the crops on two large yards in British Columbia was estimated at $\$ 80,000$.

In 1912 the loss due to this insect was particularly severe in Oregon. One company which handles about 20,000 bales estimated that 50 per cent of their hops were badly damaged and would sell for 15 cents per pound, while 30 per cent was slightly damaged and would sell between 15 and 18 cents per pound. The remaining 20 per cent was not injured and would sell for the prevailing price of 20 cents. At this rate the loss would aggregate $\$ 124,000$. The crop on a yard of 110 acres was so severely injured that 20 acres were not worth picking. The loss in this yard was $\$ 12,000$.

The damage in these cases was unusually severe, but this pest if not controlled is, under favorable conditions, capable of causing such injury to both the hopvines and the hop cones as to entail a total loss.

\section{LIFE HISTORY.}

HIBERNATION.

The winter egg is deposited by the oviparous female upon the plum, prune, and hop in the Pacific Coast States and upon the sloe, plum, bullace, ${ }^{1}$ and probably the hop in England and Continental Europe.

The first generation and the winged migrants were observed upon French prune at Santa Rosa and Perkins, Cal., during May and June in 1911 and 1912. The migrants which were observed May 29, 1912, were upon the ordinary though tender foliage, but those observed later in the season were found only upon some very succulent, suckerlike growths. No hop aphides were found upon the surrounding older and tougher leaves. This observation was made both in Santa Rosa and Perkins, and it was found that by selecting such growths aphides could almost invariably be found.

\section{APHIDES ON HOP ROOTS.}

Prof. W. T. Clarke, of the California Experiment Station, stated that while studying this insect at Watsonville, Cal., during the last of January or first of February, 1904, some hop roots were brought to him on which were many living hop aphides. He stated that there is no doubt about the identification of this insect. The writer 
was unable to find this condition, but the foregoing data show the possibility of another method of hibernation.

Many examinations of hop roots were made during this investigation, but no eggs of the hop aphis were discovered on or near them. The following data, however, lead the writer to believe that the aphides very frequently hibernate on or around the hop roots.

Wingless viviparous hop aphides were observed depositing young upon the lower leaves of a hopvine at Santa Rosa, Cal., March 16, 1912. This vine was half a mile from any prune tree. Many small wingless aphides were observed on the lower leaves of hopvines at

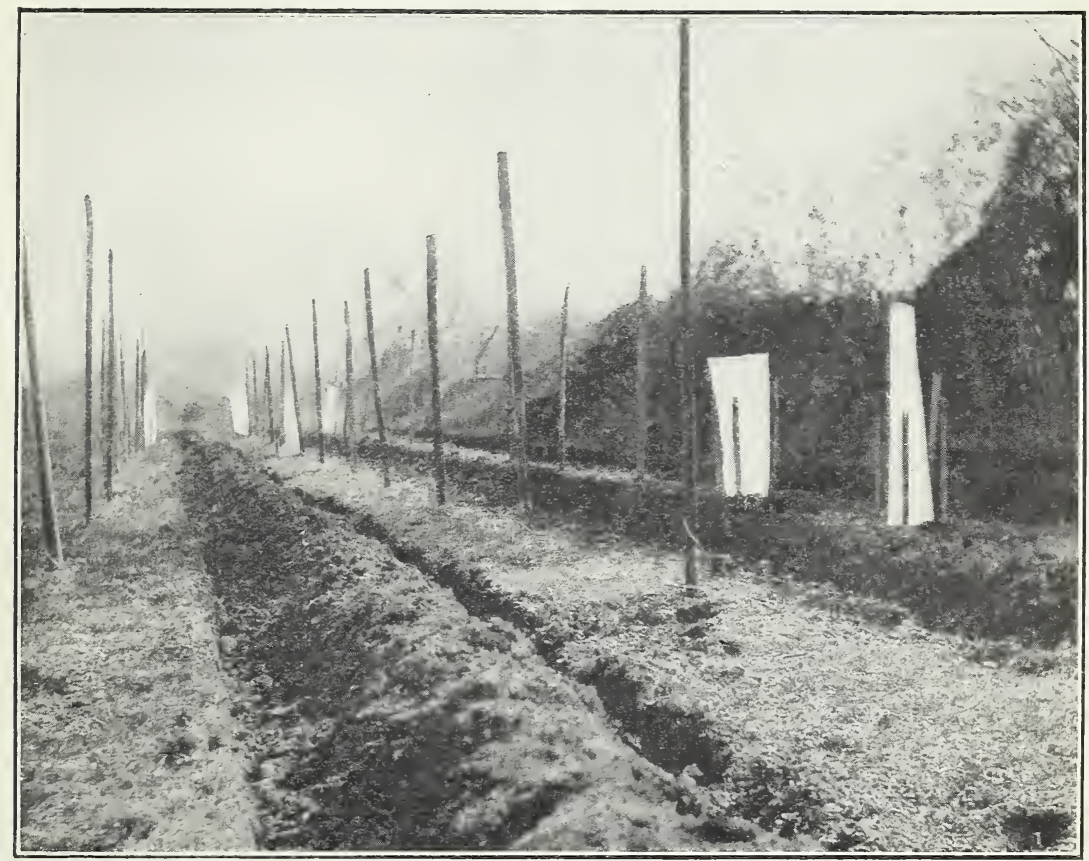

FIG. 1.-Field cages so placed as to catch any hop aphides that might emerge from eggs deposited upon the hop roots. (Original.)

Perkins, May 16, 1912. No winged migrants were observed at this time.

The first winged migrants were observed at Perkins on May 24, both on the prune and the hop, and in the latter case were only on the upper leaves, the lower leaves being entirely free.

Although field cages (fig. 1) which were placed over hopvines in February and removed after the surrounding vines were thoroughly infested did not contain any hop aphides, the fact that aphides were present on the hops before the winged migrants appeared and that they were found upon the lower leaves, while the winged forms 
collect on the uppermost leaves, seems evidence enough to establish the hop as a winter host of the hop aphis, at least in these localities.

It has been thought possible that the hop aphis may hibernate upon some plants other than the plum, prune, sloe, and hop, and during this investigation many observations were made upon plants in the vicinity of the hops, for the winter eggs. While observing the winged migrants at Independence, Oreg., they were discovered upon cherry, alder, peach, and apple, and were found depositing young upon these plants.

In order to see if the young would mature on the cherry, some infested leaves were placed in covered jelly glasses and the leaves renewed each day. These insects matured on cherry as rapidly as on plum, but as there were no males present they died without depositing any eggs. Later observations upon the same trees at Independence, however, failed to reveal any eggs upon any but the plum, on which plant they were very numerous. Although no eggs were found on these trees, the fact that the aphides could grow to full size upon the cherry indicates that under some conditions this insect may hibernate on the various plants on which it was found at Independence.

EMERGENCE FROM HIBERNATION.

Whether the eggs are laid upon the plum, prune, sloe, or hop, the aphides emerge about the same time. The exact date was not obtained, but judging from the fact that full-grown aphides were observed April 23, and allowing 13 days for growth, they must have emerged from the egg about April 10. Again, allowing 26 days for the two generations on the prune and May 24 as the date of the appearance of the first winged insects, the eggs must have hatched by April 28. This assumption corresponds very closely with data obtained at Richfield Springs, N. Y., in 1888 by Mr. Theodore Pergande, who observed the emergence of the aphides from eggs on April 5, 16, and 18 and May 10.

The insects which emerge from the sexual eggs are wingless viviparous females-"stem-mothers," so-called. They are $1 \frac{1}{2}$ to 2 millimeters $\left(\frac{1}{18}\right.$ to $\frac{1}{12}$ inch) in length, whitish green in color, and have rather long antennæ set on frontal tubercles, which are provided on the inner side with a tooth (see fig. 2). These toothed frontal tubercles are very characteristic of this species and serve well to identify it.

\section{METHOD OF REPRODUCTION.}

These viviparous insects, instead of depositing eggs, as do the sexual generations which appear in the fall, give birth to living young by a process called "budding." These young may be readily seen protruding from the tip of the abdomen. This is also the method of 


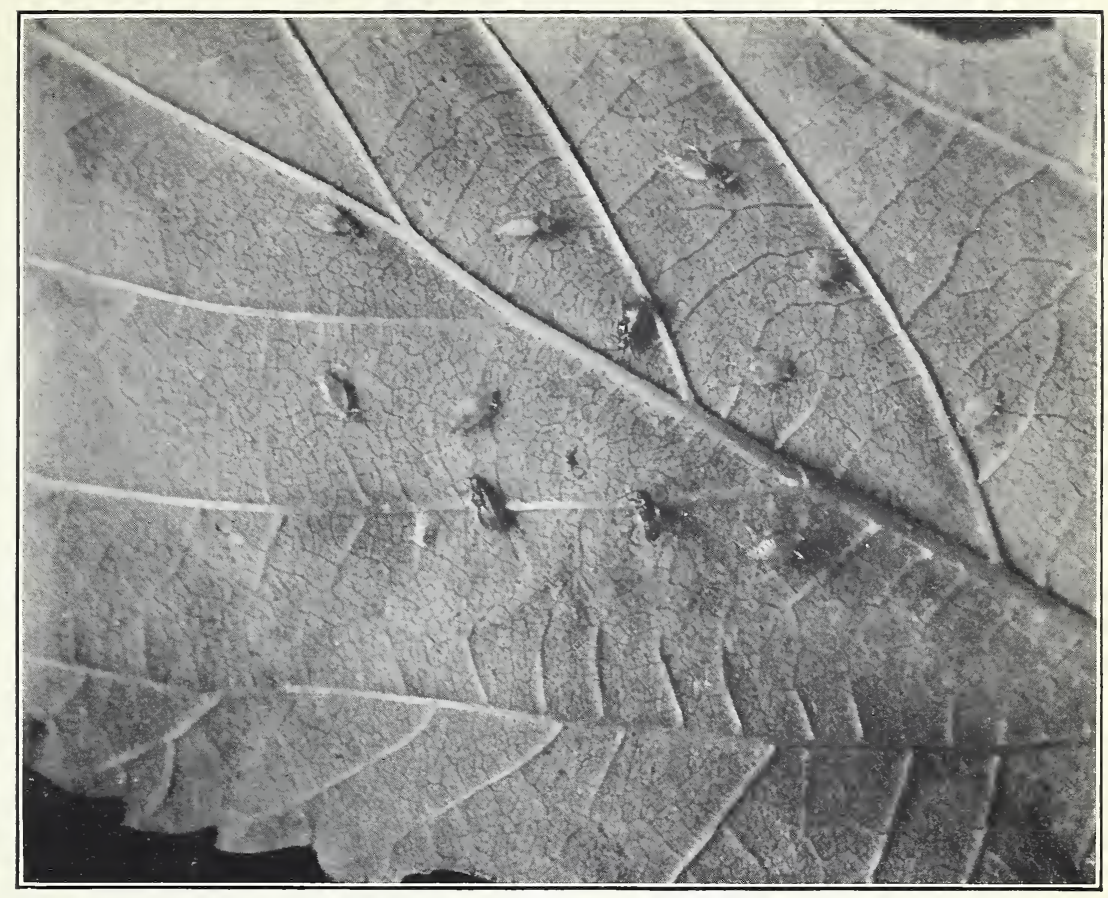

FIG. 1.-NYMPHS AND WINGEd FORMS OF THE HOP APHIS (PHOROdON HUMULI) ON HOP LEAVES. (ORIGINAL.)

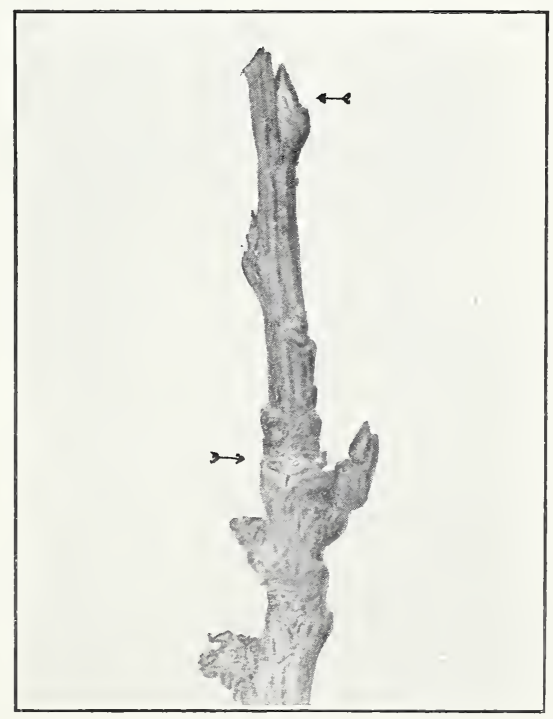

Fig. 2.-Winter Eggs of the hop aphis. Position indicated by Arrows. (Original.) STAGES OF THE HOP APHIS. 

reproduction of the winged migrants of both the spring and the fall generations. The stem-mothers are very prolific, as shown in Table III, one aphis being capable of populating several leaves in a rery short time.

\section{NUMBER OF GENERATIONS ON ALTERNATE HOST.}

Mr. Franz Remisch, of Saaz, Bohemia, who observed the emergence from the winter eggs, obtained two generations on plum. The writer did not observe the emergence of the first generation, but during the spring only two generations were found on prune, the second one being winged. In Bulletin 160 of the California experiment station Prof. W. T. Clarke reports the appearance of winged aphides 14 days after the first wingless insects were observed. This would be sufficient time for but one generation to mature, and it is very probable that there are only two generations upon the prune in the Pacific region.

\section{MIGRATING FORMS.}

The winged or migrating aphides, except for the presence of two pairs of relatively large, delicate wings, some dark spots on the thorax, and a slightly more slender body (fig. 3 and Pl. I, fig. 1) differ little from the wingless form. They appeared at Perkins, Cal., May 15 and were present

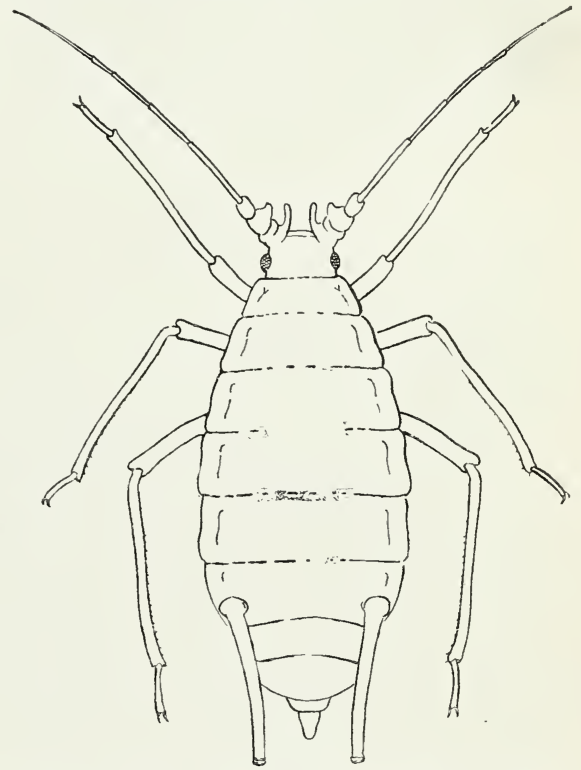

FIG. 2.-The hop aphis (Phorodon humuli): Wingless viviparous female. Greatly enlarged. (Original.)

there and at Santa Rosa until June 15. Five belated individuals were observed at Perkins the latter part of July, but the migrations had taken place by the 20 th of June.

\section{MIGRATORY ACTIVITIES.}

These winged aphides, which mature on the plum, are the first migrants. They are weak fliers, but when aided by a light wind may travel some distance. Their progeny, the wingless viviparous females, which are the most common forms found upon the hopvines throughout the season, are incapable of migration from one vine to another except where two vines come into contact so that the aphis 
can crawl from one to the other. The winged forms, therefore, are the only ones that migrate during the spring and early summer.

In the fall the winged form (fig. 3 ) that produces the sexual female migrates from the hop to its winter host-the plum, prune, sloe, or hop-and later the winged male migrates to the plant on which the sexual female awaits fertilization.

In the rearing cages and in the field during 1912 winged forms did not appear except as noted above. Winged forms were observed, however, developing upon the hopvines during the summer, at Watsonville, Cal., by Prof. W. T. Clarke, of the California Experiment Station, in 1902; by Mr. Franz Remisch, at Saaz, Bohemia; by Mr. H. N. Ord, at Independence, Oreg.; and by the writer at Santa Rosa, Cal., in 1911.

As previously stated, the winged migrants are weak fliers, but when aided by the wind may travel some distance. Some individuals were

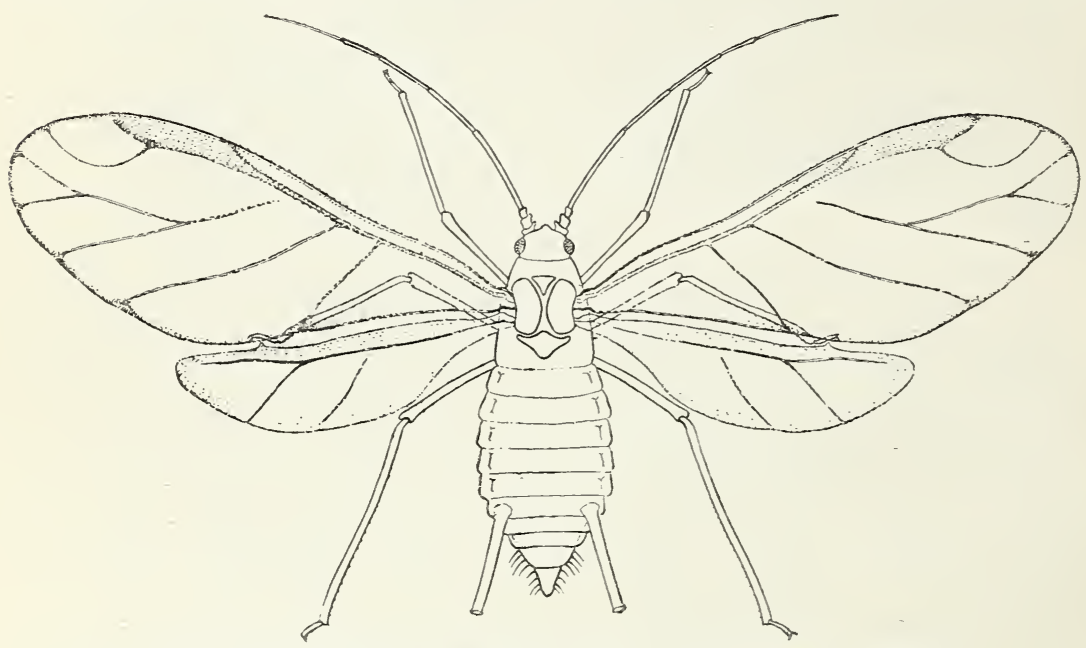

FIG. 3.-The hop aphis: Winged female migrant. Much enlarged. (Original.)

found half a mile from the infested prune trees. The infestation, however, decreases as the distance from the alternate host increases.

It was observed that more migrants collect upon the taller vines and the upper, newly expanded leaves of the other vines than upon the lower matured leaves. Very few winged aphides were observed on the fully expanded and hardened foliage, but were in every case some distance from the ground. The lower leaves were entirely free from the winged forms.

\section{DEPOSITION OF YOUNG.}

Upon reaching the hopvines these parthenogenetic migrants were observed giving birth to young, the number deposited by each individual varying between 1 and 8 , as is shown in Table $I$. 
TABLE I.-Rate of deposition of young by winged migrants of the hop aphis from prune trees.

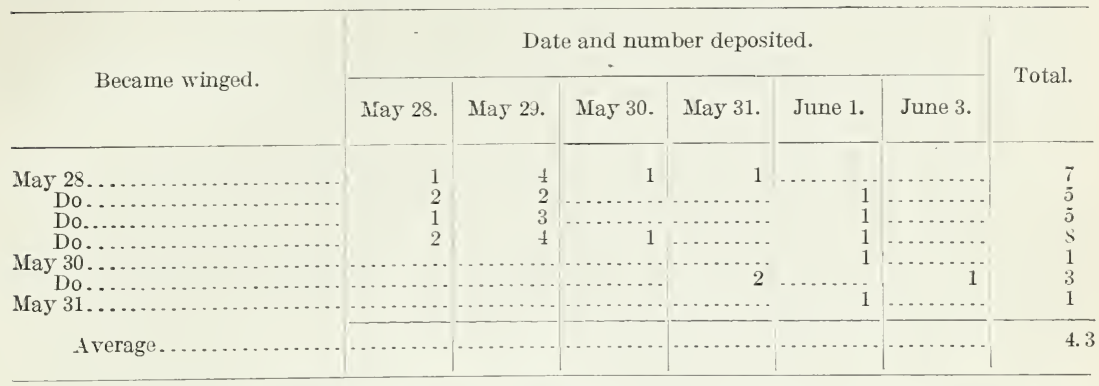

The data in Table I were obtained by isolating nymphs, taken from the prune trees, upon clean prune leaves in covered jelly glasses. When the winged insect appeared it was immediately placed upon a hop leaf. The deposited young were removed daily.

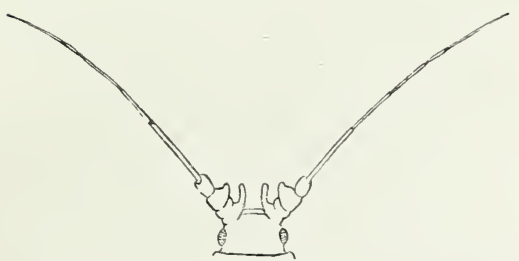

FrG. 4.-Head of hop aphis, showing frontal tubercles. Greatly enlarged. (Original.)

These young deposited by the winged aphides are wingless parthenogenic insects (Pl. II, fig. 1). They have the characteristic frontal tubercles (see fig. 4, in comparison with fig. 5) and vary in color from watery white to green. The very young insects and those that have just molted are very light, while the older ones may be quite green.

\section{RATE OF GROWTH.}

These young aphides grow very rapidly, molt four times, and immediately after the fourth molt commence depositing their young, as shown in Table II.

TABLE II.-Stages in the development of the wingless viviparous female hop aphis.

\begin{tabular}{|c|c|c|c|c|c|c|c|}
\hline No. & $\underset{\text { pesited. }}{\text { De- }}$ & $\begin{array}{l}\text { First } \\
\text { molt. }\end{array}$ & $\begin{array}{l}\text { Second } \\
\text { molt. }\end{array}$ & $\begin{array}{l}\text { Third } \\
\text { molt. }\end{array}$ & $\begin{array}{l}\text { Fourth } \\
\text { molt. }\end{array}$ & $\begin{array}{c}\text { Com- } \\
\text { menced } \\
\text { depositing } \\
\text { young. }\end{array}$ & $\begin{array}{l}\text { Total } \\
\text { days. }\end{array}$ \\
\hline $\begin{array}{l}1 \\
1 \\
2 \\
3 \\
3 \\
1 \\
1 \\
5 \\
6 \ldots \ldots\end{array}$ & $\begin{aligned} & \text { June } 11 \\
& 15 \\
& 15 \\
& 16 \\
& 18 \\
& 18\end{aligned}$ & June $\begin{array}{r}13 \\
17 \\
18 \\
19 \\
21 \\
22\end{array}$ & June $\begin{array}{r}15 \\
20 \\
21 \\
21 \\
23 \\
24\end{array}$ & $\begin{array}{r}\text { June } 17 \\
23 \\
23 \\
23 \\
26 \\
26\end{array}$ & June $\begin{array}{r}19 \\
25 \\
26 \\
25 \\
28 \\
28\end{array}$ & June $\begin{array}{r}20 \\
27 \\
27 \\
27 \\
29 \\
29\end{array}$ & $\begin{array}{r}9 \\
12 \\
12 \\
11 \\
12 \\
12\end{array}$ \\
\hline
\end{tabular}


From these experiments, which were conducted with indiridual insects, it was found that a period of from $S$ to 12 days is required for the aphides to pass through the four molts and begin depositing roung.

\section{NUMBER OF YOLYG DEPOSITED BY VIVIPAROUS FEMALES.}

Some of the experiments that were carried on to determine the number of young that are deposited by indiridual aphides are recorded in Table III.

TABLE III.-Number of young deposited by each of 12 individuals of the hop aphis.

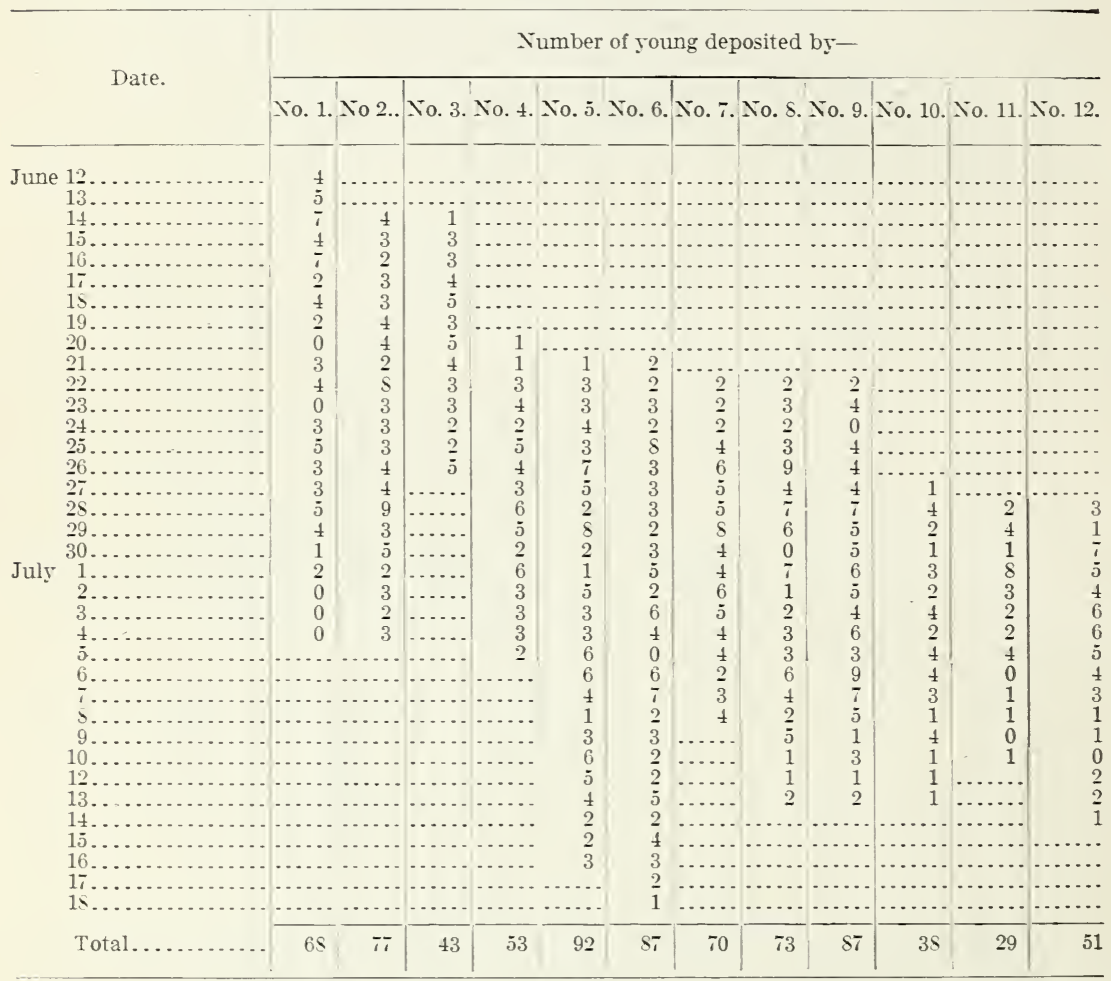

In order to obtain the foregoing data nearly mature aphides were isolated on hop leares in tin-covered jelly glasses. The leaves were changed daily and the aphides which had been deposited were removed. The number of young which are deposited by one stemmother were thus found to be from 29 to 92 , with an arerage of 64 for the 12 aphides under observation. The length of life of these aphides varied from 25 to 38 dars, with an arerage of 30.75 dars. Thus an aphis living an arerage life of 30.75 days, depositing an 
average number of young (3.3 per day) over an average period of 19 days, would give birth to 63 aphides.

At this rate of reproduction, provided that none of the aphides were destroyed before they had lived an average life, one winged aphis which settles on the hop in the spring would at the end of the fifth generation be the parent of 4,068,989,826 living aphides. These aphides would weigh 2,152 pounds. From these figures the very sudden and extensive infestations by this insect are readily explained.

\section{THE FALL MIGRANTS.}

The nymphs of the fall migrants (fig. 6) became winged in the breeding cages at Perkins, Cal., on August 26 and in the field August 28. Migrants were observed upon plum at Independence, Oreg., September 22, 1912. Young were being deposited there and upon the next visit to the locality, October 16, large numbers of male aphides were observed copulating with the sexual females that had been deposited by the migrants. Many eggs were also present at this time.

THE WINTER EGG.

The winter egg, when first deposited, is a shiny-green object, ovate in shape, and a little smaller than the head of a pin $\left(\frac{3}{4} \mathrm{~mm}\right.$. in length). Soon, however, it turns dark green and

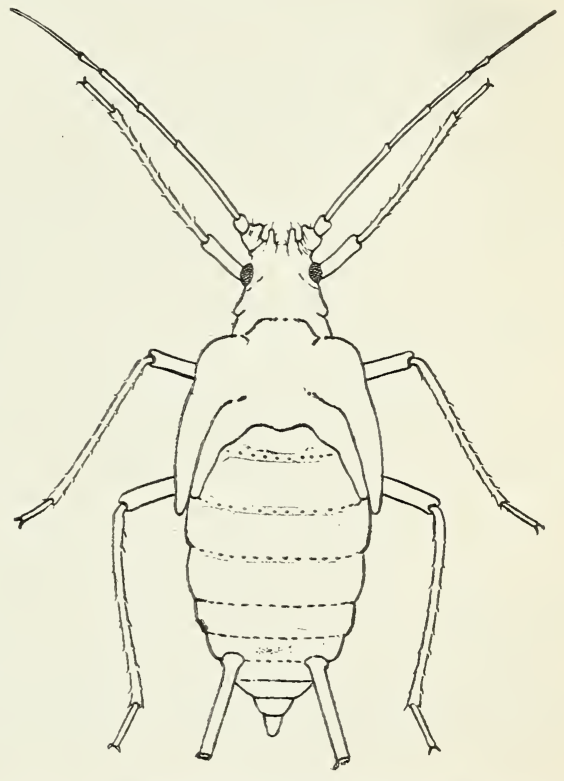

FIG. 6.-The hop aphis: Nymph, showing wing-pads. Greatly enlarged. (Original.) then black and appears as a shiny-black point (Pl. I, fig. 2) on the branch of the alternate host plant.

The eggs are usually deposited close around the buds or on the rough leaf scars, but may sometimes be found upon the smooth parts of the twigs.

\section{THE LIFE CYCLE.}

The entire life cycle where the writer's observations were made is as follows: Two generations occur on the alternate host, the second one being winged. Five and six generations occur on the hop, a part of the fifth becoming winged and depositing young upon the 74956 ${ }^{\circ}-$ Bull. 111-13- -3 
alternate host, and part being wingless and depositing young (sixth generation) upon the hop, producing the male aphides which fly to and copulate with the roung deposited on the alternate host by the winged indiriduals of the fifth generation. These fertilized females deposit the winter eggs, which, hatching in the following spring, produce the riviparous insects for that season.

Table IV gires one series of dates for the life crcle. This series will vary according to the date of the emergence of the first generation from the egg in the spring. The variation in the date of hatching of the winter eggs causes an orerlapping of generations, so that these are not in the least distinct.

TABLE IV.-Life cycle of the hop aphis as observed at Perkins, Cal.. in 1912.

Emergence from eggs..................................... June 3

Appearance of second generation, winged.......................... June 17

Appearance of third generation (first on hops)...................... June 30

Appearance of fourth generation (second on hops)................... July 11

Appearance of fifth generation (third on hops)..................... July 22

Appearance of sixth generation (fourth on hops) ...................... Aug. 2

Appearance of serenth generation (fifth on hops), part winged .............. 15

Appearance of eighth generation (sixth on hops), males .................

Appearance of eighth generation, sexual females, on plum ................ 25

Deposition of eggs............................................... 14

In the report of the Department of Agriculture for 1s8s, Prof. C. T. Riley gires the following data upon the life history, which rary somewhat from the data giren in this bulletin:

Three parthenogenic generations are produced upon Prunus, the third being winged. * * A number of parthenogenic generations are produced upon the hop until in autumn. and particularly during the month of September winged females are again produced.

This account is also at rariance with the writer's own observations in that no winged forms are noted during the summer.

\section{THEQRY REGARDING SUMMER MIGRANTS.}

The presence of winged forms of the hop aphis throughout some seasons and the absence of such forms during 1912, both in the laboratory and in the field, except at the end of the fifth generation, are explained as follows: The eggs of the hop aphis have been observed to hatch individually during a period of one month and five days, April 5 to May 10. The winged forms were observed beginning to migrate from the prune May 24, and migration was not completed until June 20. Thus until the 20th of June migrants from the alternate host (the plum or hop) were present in the hopyards. Beginning the life cycle with the first insects that migrated, the serenth or winged generation on the hop would be mature July 19. These insects, finding some tender hop leares upon which to settle, 
would deposit young thereon. The deposited young, because of climatic and succulent food conditions, might become viviparous instead of oviparous, causing a continuous increased infestation of the hopvines.

At Perkins and Santa Rosa, Cal., in 1912, a hot, dry wind early in the season destroyed practically all of the aphides which came from the alternate host, and it was the progeny of the later migrants which became winged.

These data have not been proven, but remain as the only explanation of the presence of winged aphides between the spring and fall migrations.

Since the first insects that migrate to the hop are probably the progenitors of the winged forms that occur during midsummer, it is evident that the control of the aphis early in the season will tend to reduce the numbers of the winged insects and therefore lessen the chance that thoroughly sprayed yards will become reinfested.

\section{HABITS.}

\section{HABITATION.}

Hop aphides are usually found on the underside of the leaves (Pl. II, fig. 1), but in cases of severe infestation they may be found on the upper surface as well. They gradually work up the vines, and when the hops have formed many of them may be observed inside of the cones.

\section{PROTECTION.}

Many of the aphides, especially in cases of slight infestation, will be found close to the veins and in the hollow parts of the leaves. Here, besides being protected by the sheltering leaf, they are partially protected by the surrounding wall of leaf. Other than the natural formations of the leaves the hop aphis has no protection from wind, rain, or enemies.

\section{RELATION OF ANTS TO THE HOP APHIS.}

At Perkins, and especially at Santa Rosa, Cal., a large black ant, Formica subsericea Say, was continually observed among the aphides. The habit of the ants in caring for plant lice that they may feed upon the honeydew excreted by them is historical. These ants carry the aphides to the newly expanded leaves, thus spreading the infestation. They were so active at Santa Rosa that it was found necessary to put tree tanglefoot on the vines that were used for the experiments, to prevent the ants from reinfesting them. 
FIRST APPEARANCE OF THE HOP APHIS IN THE SEASON.

The first wingless viviparous aphides of the season at Santa Rosa, Cal., at Independence, Oreg., and at Agassiz, British Columbia, were invariably observed upon hopvines near shrubby growth bordering a watercourse or fence, near a sheltering tree, or near buildings. At Santa Rosa and Agassiz, where the writer made observations during the early part of the season, the aphides were most numerous near shrubbery or buildings, the numbers decreasing

as the center of the

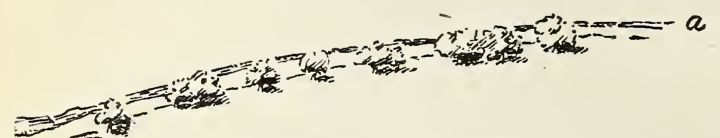
field was approached.

This condition is shown diagrammatically in figure 7 . In fact, at Santa Rosa on May 30, 1911, and June 6, 1912, the aphides occurred in numbers only near the brush, trees, or buildings, the other parts of the field being almost entirely free.

FAVORABLE AND UNFA VORABIE CONDITIONS FOR THE APHIS.

Moderately warm,

FIG. 7.-Diagram showing relative number of aphides in different parts of a single hopyard, indicating the increased infestation near Santa Rosa Creek $(a)$. (Original.) (The numbers represent approximate counts of aphides which were present on the vines June 1, 1911. On September 1 these vines were grossly infested. The row nearest the creek $(a)$ is row 1 ; the next is row 2; and after that the numbers were taken from every fifth row. Each number represents the number of aphides found on the hill in that location.)

and the most severe infestations occur during seasons of such weather.

A hot, dry wind is very unfavorable to the aphides and in some sections, when followed by dry, warm weather, will materially check infestation.

\section{EFFECT OF HEAT.}

Some careful observations on the condition of the hop aphis after continued hot weather, and especially when the hot weather was accompanied by a north wind, were made at Perkins, Cal. 


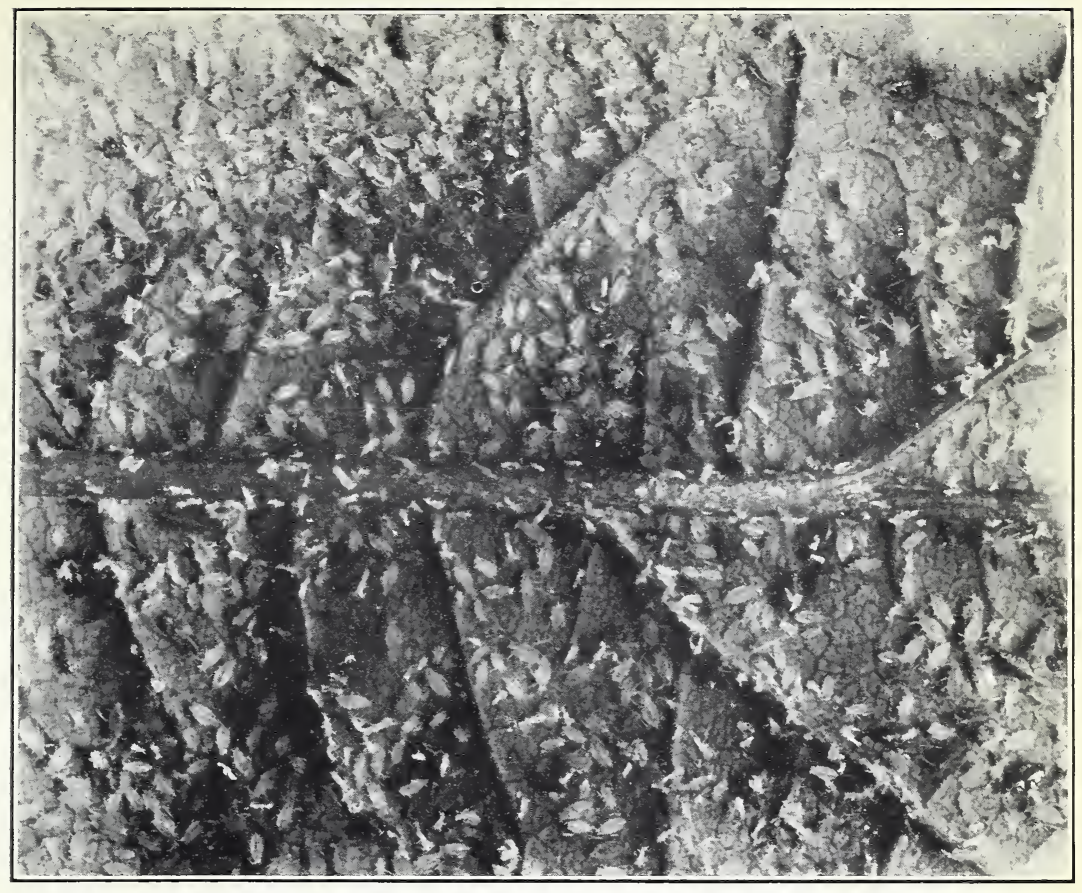

Fig. 1. - Wingless Progeny of Winged Hop Aphides from Alternate Host. (ORIGINAL.)

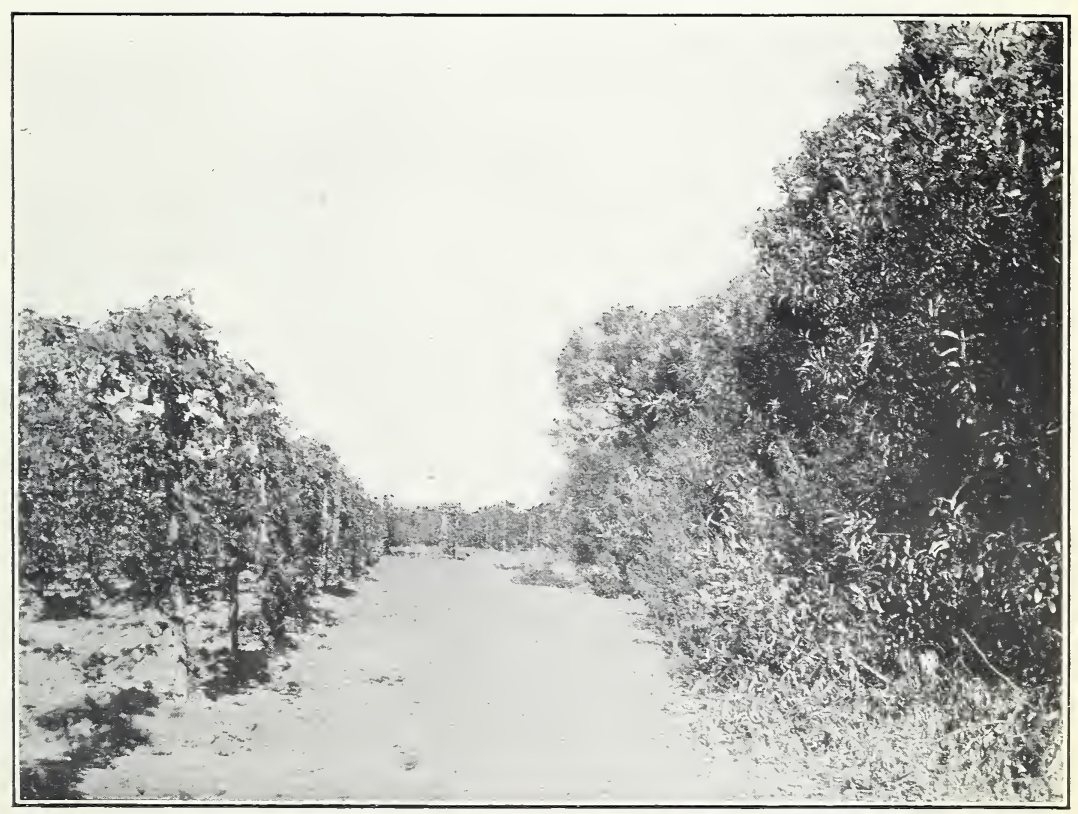

Fig. 2.-Willows Along Edge of Hopyard, Which Were ERroneously Supposed to HARBor HOP APHIDES. (ORIGINAL.) 


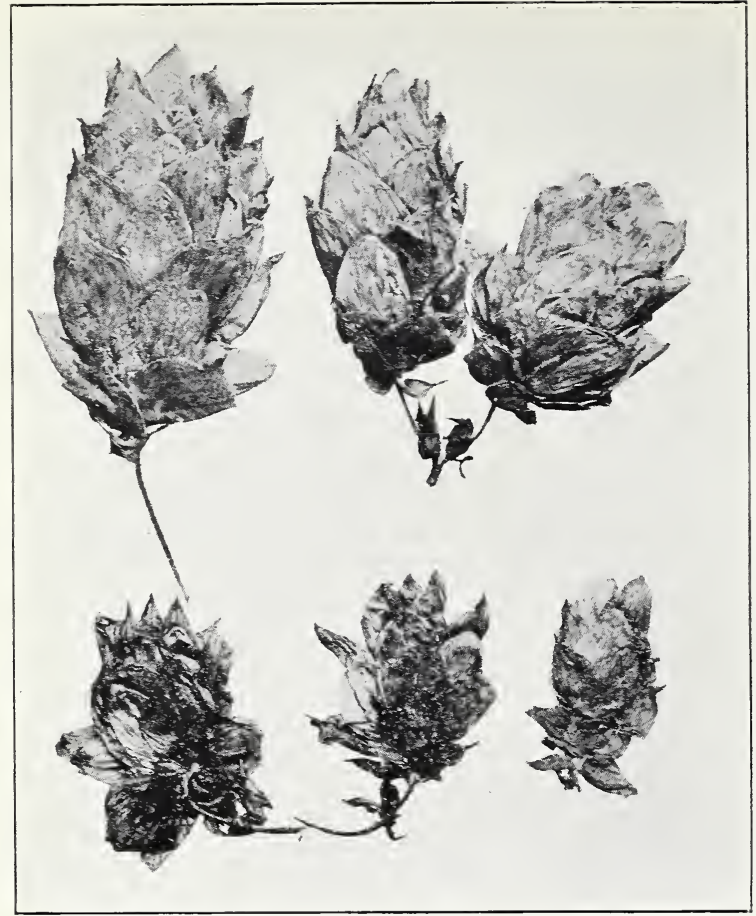

FIG. 1.-UPPER ROW, NORMAL HOP CONES; LOWER ROW, HOP CONES INJURED by THE HOP APHIS. (ORIGINAL.)

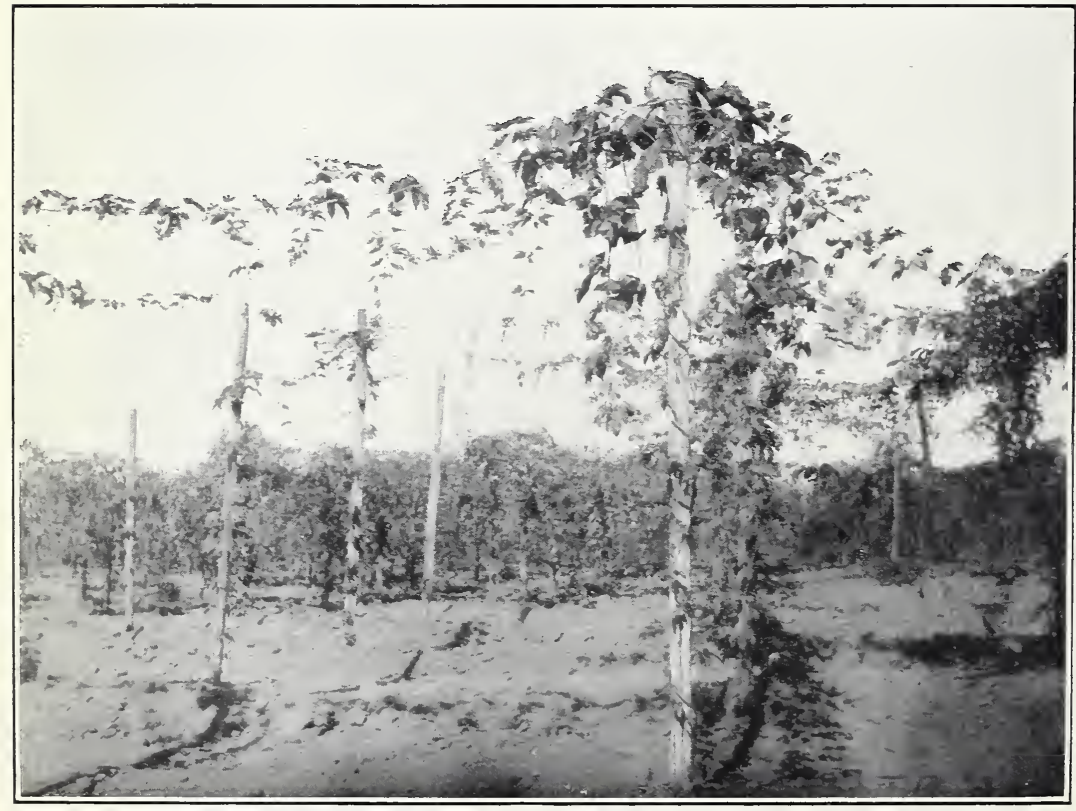

FIG. 2.-VINES IN FOREGROUND SEVERELY INJURED BY THE HOP APHIS SHOWING LACK of Growth as Compared with Uninjured Vines in the Distance. (Original.) 


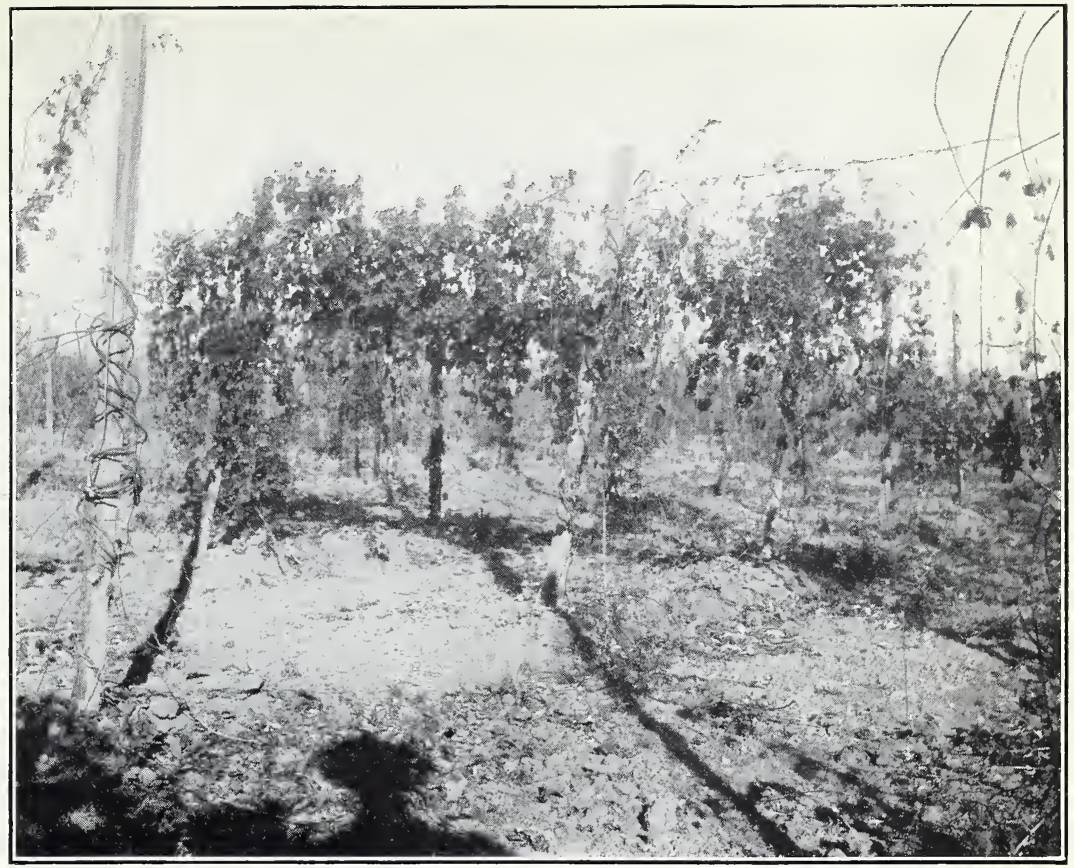

Fig. 1.-Hopvines SeVerely INJUREd by THE Hop APHIS, AND LefT IN THE FIELD. (ORIGINAL.)

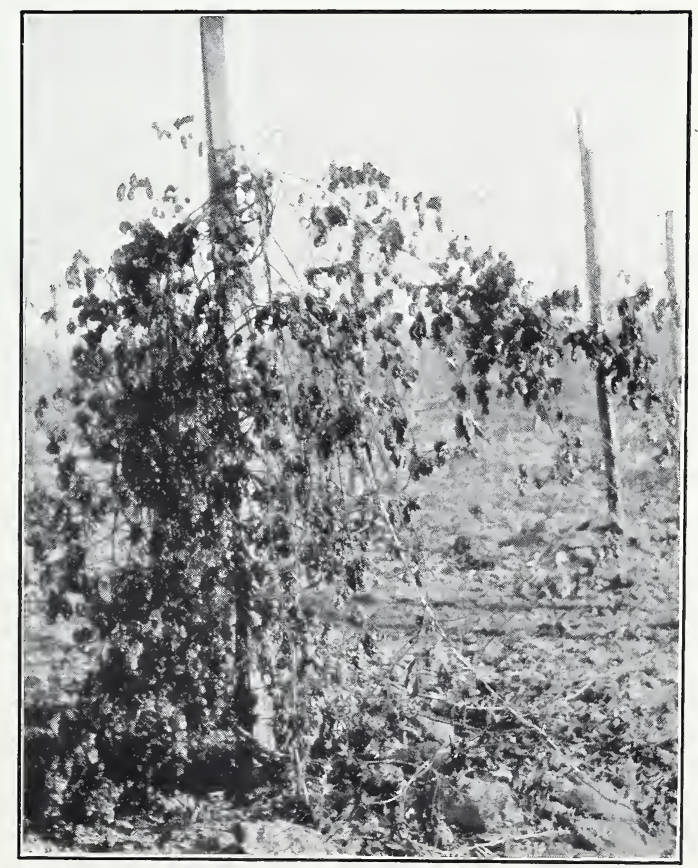

Fig. 2.-EnLarged View of Damaged and Moldy Hopvines. (Original.) INJURY TO HOPVINES BY THE HOP APHIS. 


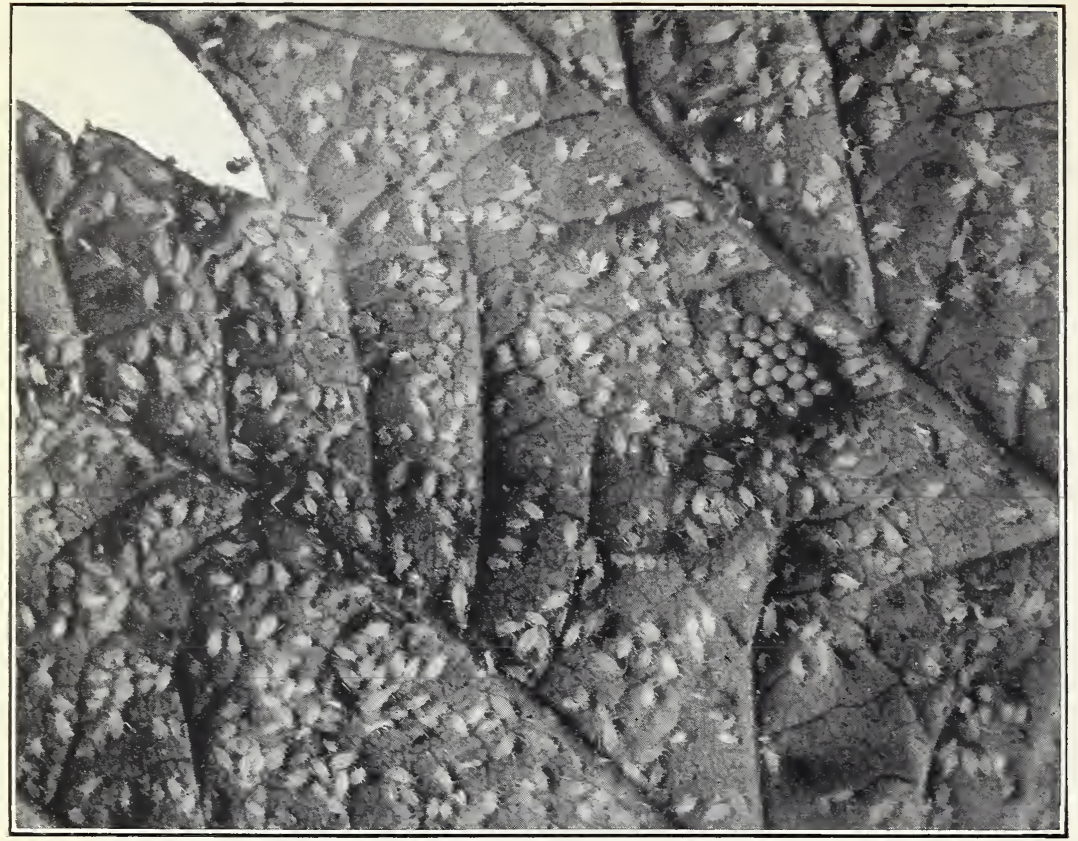

Fig. 1.-Eggs of hippodamia convergens among Hop aphides on leaf. (Original.)

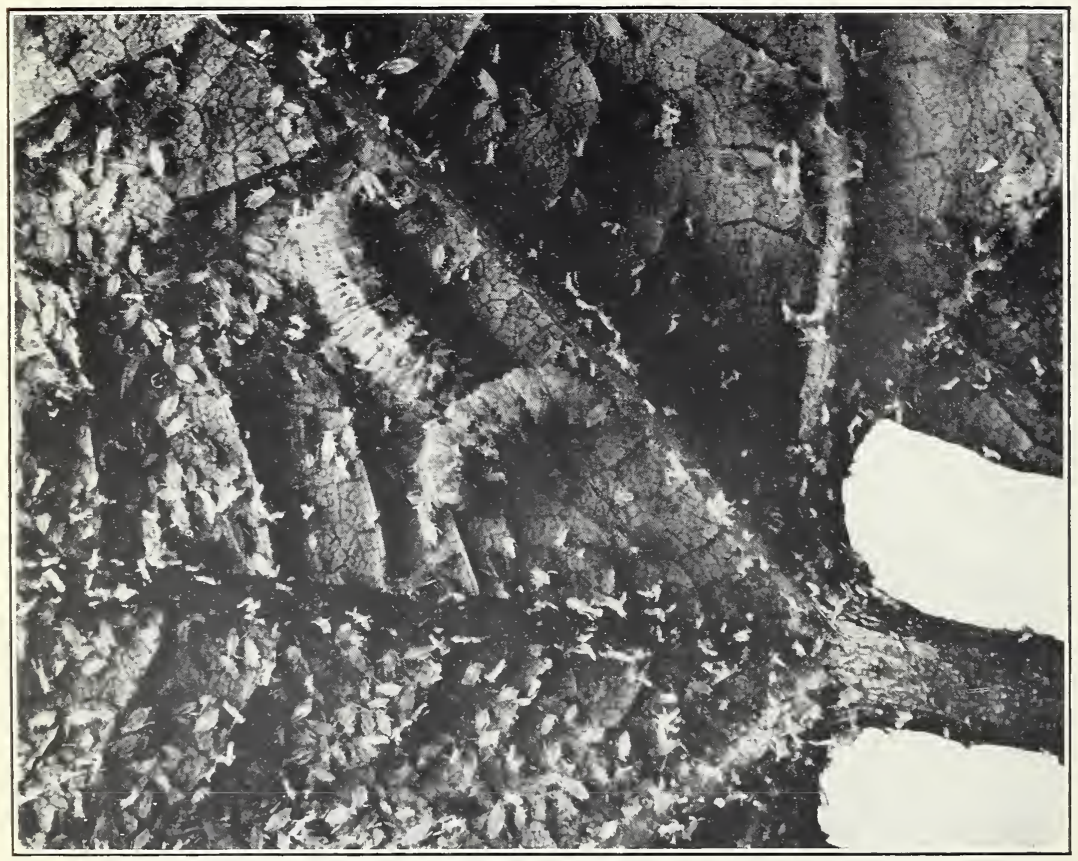

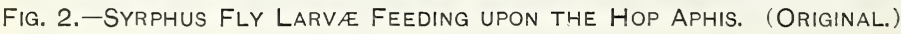
SOME NATURAL ENEMIES OF THE HOP APHIS. 
It was noticed that in every case where the aphides were reduced by the effect of the heat, some small ones remained and upon maturing produced the following generation. In some cases not a single full-grown aphis was found after the hot weather had ceased, but many of the young aphides were present upon the vines. A similar observation was made at Santa Rosa, Cal.

\section{FOOD PLANTS.}

Phorodon humuli feeds principally upon the hop. It has, however, some alternate food plants on which the sexual forms develop. (See p. 14.)

It is a common belief that the aphides found upon the shrubs and trees growing near the hopyards (see Pl. II, fig. 2) are hop aphides and that they later migrate to the hops. Specimens of aphides were taken from various plants growing near the hopyards at Agassiz, British Columbia, Independence, Oreg., and Santa Rosa, Cal., and identified. In no case was Phorodon humuli found among the aphides collected. Even though aphides may be extremely numerous upon such near-by plants, they do not in the least menace the hop crops; hence their destruction, from the standpoint of hop-aphis control, is unnecessary.

\section{NATURE OF DAMAGE.}

\section{GENERAL EFFECT OF APHIDES UPON HOPS.}

The hop aphis injures the crops in two ways: By extracting the plant juices it prevents the normal growth of the plant, and by the excretion of honeydew, on which grows the black-smut fungus, Cladosporium sp., it injures the quality of the crop.

In one hopyard at Santa Rosa, Cal., May 31, 1911, several vines were found which were severely infested. Later in the season these vines were observed to have made little growth. The few hop cones which had formed were very small, some being only slightly larger than the burrs. Plate III, figure 1, shows some of these small cones compared with normal cones which were taken from near-by uninfested vines. The relatively small growth of the infested vines compared to that of the uninfested vines is well illustrated in Plate III, figure 2. The vines in the foreground were severely injured by the aphides, while those farther back were only slightly infested until late in the season and made a very fair growth.

Some vines that were only slightly infested were observed throughout the season. These vines grew well and bore a fine crop of hops, but just before the harvest the aphides entered the cones, extracted their vitality, and covered the scales with honeydew, in which the black-smut fungus soon established itself. These cones were so 
severely injured that they were not worth picking, and they were left in the field. (See Pl: IV, figs. 1, 2.)

Where control work is attempted the infestation seldom becomes so severe as to retard the growth of the vines, and it is the late injurythe accumulation of honeydew upon the cones and the resulting growth of the black fungus - which is most to be feared.

HONEYDEW AND ITS EFFECT ON THE HOPS.

Honeydew is a substance which is excreted from the anal opening of the aphides. It is composed largely of gums and sugar and is sticky and sweet to the taste. On warm afternoons it may be seen falling as a mist from severely infested vines.

Hops covered with honeydew are sticky, do not have the normal amount of crispness, and when pressed between the fingers remain flattened out. Honeydew may under some circumstances increase the weight of the crop. One grower estimated that he made $\$ 1,000$ on honeydew in 1911. However, the quality of the crop was greatly injured, and had the demand for hops been less the grower would not have been able to sell, and his crop would have been a complete loss.

Even though under certain uncontrollable circumstances the presence of honeydew may increase the income from a crop of hops, their quality is injured, and the honeydew is the medium for the black-smut fungus, which will, in ninety-nine cases out of one hundred, so injure the quality of the crop that it will be unsalable.

\section{BLACKENING OF HOPS.}

Neither the honeydew nor the aphides are directly responsible for the blackening of the hops. The blackening is due to a smut fungus (Cladosporium sp.) commonly called "mold," which grows upon the honeydew. If the honeydew happens to be upon the hop cones, this fungus gives the hops a black, moldy appearance, which is extremely undesirable.

\section{NATURAL ENEMIES.}

Several predaceous insects have been observed attacking the hop aphis at Perkins and at Santa Rosa, Cal. The ladybirds Hippodamia convergens Guér., Coccinella californica Mannh., Coccinella abdominalis Say, and Chilocorus orbus Cas. were frequently found among the aphides. Some eggs of Hippodamia convergens deposited among the hop aphides are shown in Plate V, figure 1. Chrysopa californica Coq. was always abundant in the hop fields, and the larvæ were very active in feeding upon the aphides.

The larvæ of syrphus flies (Pl. V, fig. 2) were abundant in the hopyards. Syrphus opinator O. S. and Syrphus americanus Wied. were reared from the larvæ which were collected from hop leaves. 
A small predaceous bug, Triphleps insidiosus Say, was occasionally observed among the aphides.

The following insects were observed by Mr. Theo. Pergande attacking the hop aphis at Richfield, N. Y., in 1887:

Triphleps insidiosus Say

Adalia bipunctata L.

Stethorus punctum Lec.
Camptobrochis nebulosus Uhl.

Anthocoris sp.

Parasites and predaceous insects destroy large numbers of hop aphides, but in no case have they been observed successfully to control an infestation.

\section{CONTROL OF THE HOP APHIS.}

\section{AXIOMS OF SUCCESSFUL CONTROL.}

In the economic control of the hop aphis, as of other insect pests, there are certain underlying principles which must be adhered to if the work is to be entirely successful.

(1) All of the machinery to be used must be capable of doing effective work and must be in good working condition prior to the time at which spraying should commence.

(2) Spraying must commence at the proper time; it must not be put off.

(3) The material used must be carefully prepared and thoroughly but not wastefully applied.

These are fundamental principles, and control work will be less effective and more costly if they are not closely adhered to.

\section{INSECTICIDES USED}

Several contact insecticides have been used to control the hop aphis. The most extensively used sprays, howerer, are tobacco decoctions with whale-oil soap and quassia chips with whale-oil soap. In order to obtain exact data upon the effectiveness of these materials upon the hop aphis a series of experiments on a small scale was conducted at Santa Rosa, Cal., and notes were taken from experiments made on a large scale in Oregon. Tag counts were made; i. e., 20 tags were tied to as many leaves, and records of the number of aphides on the leaves before and three days after spraying were made on the tags; the percentage of aphides killed was thus accurately obtained.

\section{TIME TO BEGIN SPRAYING.}

It is very desirable to spray all plums or prunes that are infested by hop aphides as soon as the infestation is observed, both in the fall and in the spring. This will check the migration and lessen the infestation of the hops. The hops, however, should be sprayed as soon as the 
aphides become numerous. This is usually from June 1 to 15 , though in some cases it may be earlier. It is well to spray first the fields which are most seriously infested.

It is usually desirable to wait until the vines are stripped before spraying.

\section{NUMBER OF APPLICATIONS.}

The number of applications which are necessary to control the aphides will vary with the seasonal and local conditions. The object is to prevent injury to the vines and to have the vines practically free of aphides at the time hop picking commences. To obtain good results it is usually necessary to spray the vines from two to four times.

\section{NECESSITY FOR EARLY SPRAYING.}

Mr. H. N. Ord, who directed some very successful spraying operations in a large hopyard in Oregon, claims that the secret of his success was early spraying. He began before the aphides became very numerous and continued as long as there were any aphides in the field. Yards sprayed under Mr. Ord's direction were practically free from aphides, while the crops of a near-by grower were so severely damaged that 10 acres were left in the field unpicked.

\section{NECESSITY FOR THOROUGH WORK.}

The insecticides which are used for the hop aphis kill only by actual contact, and if satisfactory results are to be obtained it is absolutely necessary that the spray be thoroughly applied. Running the spray up and down the rine is not sufficient, because all of the leaves must be thoroughly wetted on both surfaces if good results are to be obtained.

\section{PROCRASTINATION.}

In sections where the aphides are frequently controlled by weather conditions some growers are likely to delay control work, hoping that a hot, dry wind will relieve them of the necessity of spraying. In one hop-growing section of California such a wind has appeared regularly for several years, but during the past two seasons (1911-12), which were favorable for the aphides, it did not arrive. Many growers, depending upon this wind, made no effort to control the aphides until late in the season, when much damage had been done. It was then difficult to make much progress against the insects, and severe injury resulted.

\section{SPRAYING EXPERIMENTS.}

The nicotine solutions appeared to be the most promising materials and were therefore the most extensively used in the experiments. The following tables, arranged according to relative costs, 
show the results of these experiments and give the cost of the materials per 100 gallons of spray:

TABLE V.-Results of spraying experiments for the hop aphis, with costs of materials per 100 gallons of spray.

\begin{tabular}{|c|c|c|c|c|c|c|c|}
\hline $\begin{array}{l}\text { Experi- } \\
\text { ment } \\
\text { No. }\end{array}$ & Materials used. & Pressure. & $\begin{array}{c}\text { Number } \\
\text { of } \\
\text { aphides. }\end{array}$ & $\begin{array}{l}\text { Per cent } \\
\text { killed. }\end{array}$ & $\begin{array}{c}\text { Date } \\
\text { sprayed. }\end{array}$ & $\begin{array}{l}\text { Date } \\
\text { counted. }\end{array}$ & $\begin{array}{l}\text { Cost per } \\
100 \text { gal- } \\
\text { lons. }\end{array}$ \\
\hline 1 & Nicotine sulphate, 1 to 3,000 . & $\begin{array}{l}\text { Pounds. } \\
80-100\end{array}$ & $1.22 \pi$ & 99.9 & June 15 & June 17 & s0 416 \\
\hline $\begin{array}{l}1 \\
2\end{array}$ & Nicotine sulphate, 1 to $2,000 \ldots$. & .. $80-100$ & 1,005 & 97.8 & June 13 & ... do..... & $\begin{array}{l}30.410 \\
.62\end{array}$ \\
\hline 3 & $\begin{array}{l}\text { Nicotine sulphate, } 1 \text { to } 3,000 \text {; } \\
\text { whale-oil soap, } 4 \text { to } 100 \text {. }\end{array}$ & $80-100$ & 3,089 & 99.2 & June 14 & ...do.. & .80 \\
\hline 4 & $\begin{array}{l}\text { Nicotine sulphate, } 1 \text { to } 3,000 \text {; } \\
\text { cresol soap, } 1 \text { to } 300 \text {. }\end{array}$ & $80-100$ & 1,990 & 95 & June 15 & ....do. & .83 \\
\hline $\begin{array}{l}5 \\
6\end{array}$ & Blackleaf tobacco, 1 to 75 & $\begin{array}{l}80-100 \\
80-100\end{array}$ & $\begin{array}{l}3,474 \\
1.810\end{array}$ & $\begin{array}{l}84 \\
94\end{array}$ & $\ldots$ do $\ldots . .$. & ... do.... & .83 \\
\hline$\frac{0}{7}$ & $\begin{array}{l}\text { Nicotine sulphate, } 1 \text { to } 2,000 ; \\
\text { cresol soap, } 1 \text { to } 300 \text {. }\end{array}$ & $\begin{array}{l}80-100 \\
80-100\end{array}$ & $\begin{array}{l}1.810 \\
2.320\end{array}$ & $\begin{array}{l}94 \\
97\end{array}$ & ... do do....... & $\begin{array}{ll}\text { (..do... } \\
\text {... do... }\end{array}$ & 1.04 \\
\hline $\begin{array}{l}8 \\
9\end{array}$ & Blackleaf tobaceo, 1 to $60 \ldots \ldots$. & $80-100$ & 2,590 & 99.8 & ..do..... & ...do... & 1. 08 \\
\hline $\begin{array}{r}9 \\
10\end{array}$ & $\begin{array}{l}\text { Nicotine sulphate, } 1 \text { to } 1,000 \text {. } \\
\text { Nicotine sulphate, } 1 \text { to } 2,000 \text {; } 1 \text { - }\end{array}$ & $\begin{array}{l}80-100 \\
80-100\end{array}$ & $\begin{array}{r}654 \\
2.225\end{array}$ & $\begin{array}{l}98.2 \\
99.1\end{array}$ & $\begin{array}{l}\text { June } 13 \\
\text { June } 15\end{array}$ & (...do.... & $\begin{array}{l}1.25 \\
1.37\end{array}$ \\
\hline 11 & $\begin{array}{l}\text { resin soaps. } \\
\text { Nicotine sulphate, } 1 \text { to } 1,000 \text {; } \\
\text { whale-oil soap, } 4 \text { to } 100 \text {. }\end{array}$ & $80-100$ & 2,512 & 99.4 & June 14 & ...do.... & 1.42 \\
\hline 12 & $\begin{array}{l}\text { Nicotine sulphate, } 1 \text { to } 1,000 \text {; } \\
\text { cresol soap, } 1 \text { to } 300 \text {. }\end{array}$ & $80-100$ & 2,780 & 99 & June 15 & ...do... & 1.67 \\
\hline
\end{tabular}

INEFFECTIVE MATERIALS.

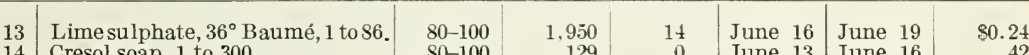

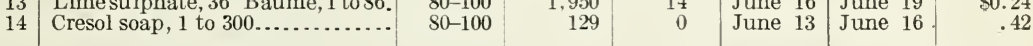

From the data in Table $\mathrm{V}$ it is evident that all the experiments except Nos. 5, 13, and 14 were quite satisfactory and that Nos. 1, 2,3 , and 4 were the cheapest materials to use. It was found that the nicotine sulphate without soap did not spread very readily and that the good results obtained were due to the rery careful application. Either flour paste or soap should alwars be used with the nicotine solutions.

TABLE VI.-Spraying experiments conducted in Oregon against the hop aphis during 1911.

\begin{tabular}{|c|c|c|c|c|c|c|c|}
\hline 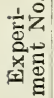 & Materials used. & Pressure. & $\begin{array}{c}\text { Number } \\
\text { of } \\
\text { aphides. }\end{array}$ & $\begin{array}{l}\text { Per cent } \\
\text { killed. }\end{array}$ & $\begin{array}{l}\text { Date } \\
\text { sprayed. }\end{array}$ & $\begin{array}{l}\text { Date } \\
\text { counted. }\end{array}$ & $\begin{array}{c}\text { Cost per } \\
100 \\
\text { gallons. }\end{array}$ \\
\hline 1 & Tobacco waste, 25 pounds to 100 & $\begin{array}{r}\text { Pounds. } \\
100\end{array}$ & 213 & 100 & Aug. 22 & Aug. 25 & $\$ 0.18$ \\
\hline 2 & Tobacco waste, $27 \frac{1}{2}$ pounds to 100 & 100 & 253 & 100 & ...do.. & Aug. 24 & .20 \\
\hline 3 & Nicotine sulphate, 1 to $2.000 \ldots . . .$. . & 100 & 695 & 89 & Aug. 21 & Aug. 23 & .62 \\
\hline & $\begin{array}{l}\text { Nicotine sulphate, } 1 \text { to } 2,000 \text {; whale- } \\
\text { oil soap, } 5 \text { to } 100 . \ldots \ldots \ldots \ldots \ldots\end{array}$ & 100 & 529 & 98 & & ... do. & .845 \\
\hline $\begin{array}{l}5 \\
6\end{array}$ & $\begin{array}{l}\text { Nicotine sulphate, } 1 \text { to } 1,000 \ldots \\
\text { Nicotine sulphate, } 1 \text { to } 2,000 \\
\text { whale- }\end{array}$ & 100 & 73 & 100 & ... do. . & ...do.... & 1.25 \\
\hline & $\begin{array}{l}\text { oil soap, } 5 \text { pounds to } 100 \text { gallons } \\
\text { water................................ }\end{array}$ & 100 & 491 & 98 & & $\ldots$ do.... & 1.475 \\
\hline 7 & Nicotine sulphate, 1 to $750 \ldots \ldots . \ldots$. & 100 & 130 & 97 & Aug. 22 & Aug. 25 & 1.66 \\
\hline
\end{tabular}


Table VI represents the work done in Oregon by Mr. H. N. Ord and is in part a repetition of the results recorded in Table V. It also contains data upon tobacco waste, which appears very satisfactory and very cheap. If the decoction is allowed to boil or the tobacco happens to be low in nicotine, the spray will not be effective, and the vines will have to be resprayed.

If this material be used each tankful should be tested upon some aphides and a record of efficiency kept. It is for these reasons not so satisfactory as a material containing a known quantity of insecticide.

Nicotine-sulphate formulas for 100-gallon lots.

Ounces.

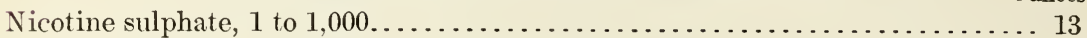

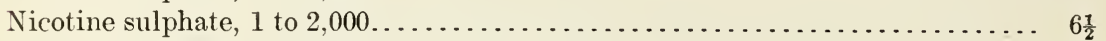

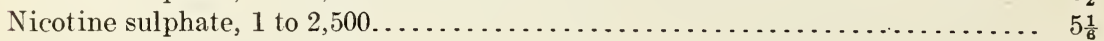

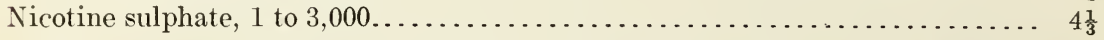

The formula " $4-100$," given for flour paste, means 4 gallons of flour paste (made according to directions) to each 100 gallons of spray. This paste contains 1 pound of flour in each gallon, so that there would be 4 pounds of flour (in the form of paste) in each 100 gallons of spray.

The formula "4-100," when referring to whale-oil soap, means 4 pounds of whale-oil soap to 100 gallons of spray.

Flour paste had proved to be a most efficient, cheap, and convenient spreader for the lime-sulphur solutions. ${ }^{1}$ Some experiments were conducted during 1912 with this material in combination with nicotine sulphate against the hop aphis. Table VII gives some of the results obtained with this mixture.

TABLE VII.-Experiments in the control of the hop aphis by sprays of nicotine sulphate and flour paste.

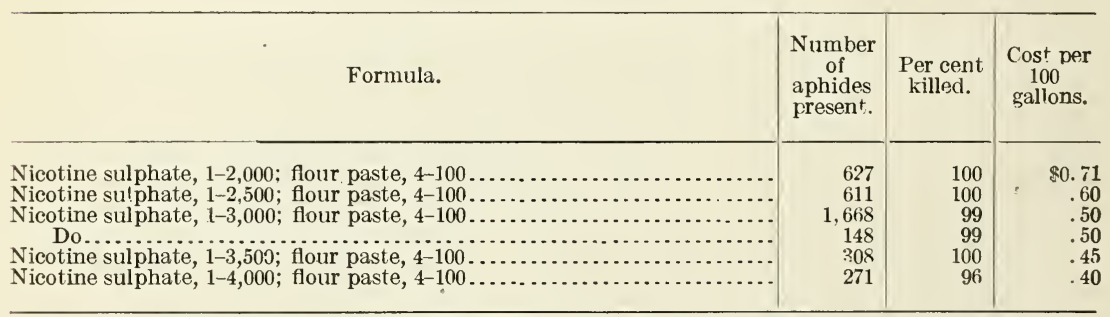

From the results noted in the preceding tables it is evident that nicotine sulphate is effective in dilutions as high as $1-3,500$, and that flour paste, $4-100$, is an effective spreader for this material. The nicotine sulphate, $1-4,000$, was not quite so effective, and it was also observed that its action was so slow that the sprayed aphides were able to deposit young on the leaves, thus reinfesting the hopvines. 
Nicotine sulphate, 1-3,000 and 1-3,500, in combination with whale-oil soap or flour paste has been successfully used in experiments, but it would be safer in practice to use the lower dilutions. In case the greater dilutions are used, careful observations should be maintained to be sure that the spray is doing effective work. The nicotine preparations which come in cans have a slight tendency to settle. In case they do settle and are not thoroughly mixed before measuring, the percentage of active insecticide used in one lot of spray may be enough less than should be present in a uniform portion to render the spray ineffective. It is advisable, therefore, to be sure that these preparations are thoroughly mixed before measuring.

\section{MIXING NICOTINE SOLUTIONS AND WHALE-OIL SOAP.}

During certain spraying experiments with tobacco extracts and whale-oil soap some difficulty was experienced in mixing the concentrated solutions of blackleaf tobacco and whale-oil soap. When these were combined a greenish-gray precipitate of a flocculent nature was formed. A similar precipitate occurred when one of the materials was diluted and the other left concentrated. When each solution was diluted to half of the final amount, however, this objectionable nozzle-clogging precipitate did not appear.

Flour paste does not have this effect, but when whale-oil soap is used as a spreader for tobacco sprays, both solutions must be well diluted before mixing.

\section{PREPARATION OF THE FLOUR PASTE.}

In preparing the flour paste, mix a cheap grade of wheat flour with cold water, making a thin batter without lumps, or wash the flour through a wire screen with a stream of cold water. Dilute until there is 1 pound of flour in each gallon of mixture. Cook until a paste is formed, stirring constantly to prevent caking or burning. (See Pl. VI, fig. 1.) Add sufficient water to make up for evaporation.

If the paste is not sufficiently cooked, the resulting spray will not be effective. If overcooked; the paste will harden when thoroughly cool; it will then not mix with water very readily. Usually, however, the paste is used as it is prepared, and overcooking is not a disadvantage.

When mixed in a spray tank flour paste has a tendency to settle, and in order to do satisfactory work agitation is necessary. This is only a slight disadvantage, however, and is necessary with most spray materials. The large spray tanks are usually fitted with an agitator, and a hoe makes an effective agitator for the 50-gallon barrels, so that this problem is a simple one. 
ADVANTAGES OF FLOUR PASTE OVER WHALE-OIL SOAP AS A SPREADER FOR CONTACT INSECTICIDES.

Flour paste costs 8.8 cents per 100 gallons of spray. Cheap flour is always available, and the paste has no odor. Whale-oil soap costs 20 cents per 100 gallons of spray, is not always available, and has a disagreeable odor.

Both materials have to be heated before using.

The neutrality of flour paste was proven by the fact that when applied upon the foliage and blossoms of the hop, in proportions as high as 12 gallons of paste to 100 gallons of spray, no injurious effects resulted. When sprayed upon the hop burrs and delicate hop cones, it did not prevent pollination or injure the appearance of the scales.

\section{QUASSIA.}

Quassia is the extract from the wood of Picræna excelsa, a tree occurring in Jamaica and containing the alkaloid quassin $\left(\mathrm{C}_{32} \mathrm{H}_{42} \mathrm{O}_{10}\right)$ in the form of crystalline rectangular plates. Quassia chips contain no tannic acid.

\section{EFFECT OF QUASSIA ON APHIDES.}

A solution of quassia containing the extract from 5.33 ounces of quassia chips in 1 quart of water was diluted one-half and sprayed on Hyalopterus pruni on prune. It was found necessary to wash the waxy pulverulence from the insects before they could be wetted. The leaves were tagged with the numbers of aphides present and the twigs set into water in the laboratory. A check branch was sprayed with pure water. That the strong quassia solutions have a decided insecticidal value is shown by the following data:

Aphides present before spraying, 37, 40, 109, 92, 190, 75, 140, 40; total, 723.

Aphides present after spraying, 0, 30, 3, 1, 0, 25, 0, 0; total, 59 .

Per cent killed, 92.

Quassia solution at the rate of 7 pounds of chips to 250 gallons of water was applied to the aphides with the following results:

A phides present before spraying, 48, 60, 30, 40, 73, 30, 200, 100, 63, 128, 12; total, 784 . Aphides present after spraying, 0, 0, 5, 0, 0, 0, 1, 2, 7, 9, 10; total, 34 .

Per cent killed, 96 .

The aphides on sprayed leaves turned brown when dead. The check leaves contained living insects only. 


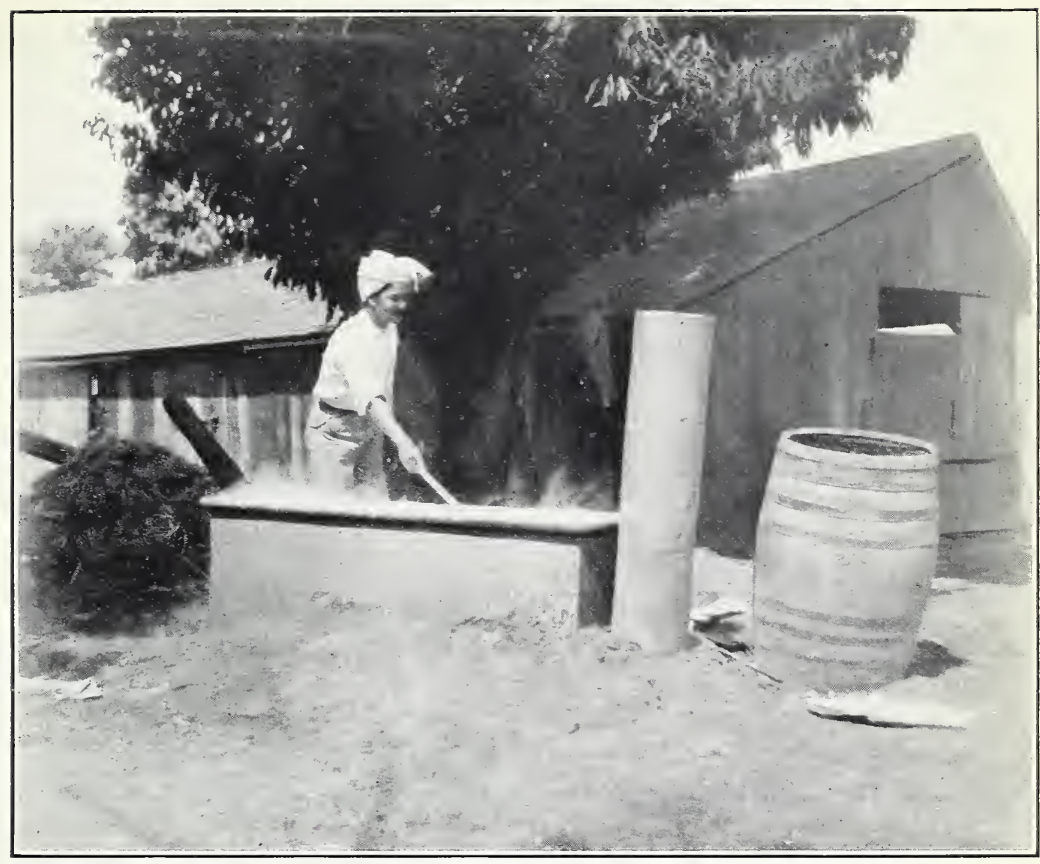

Fig. 1.-Hindu laborer Cooking Flour Paste. (Original.)

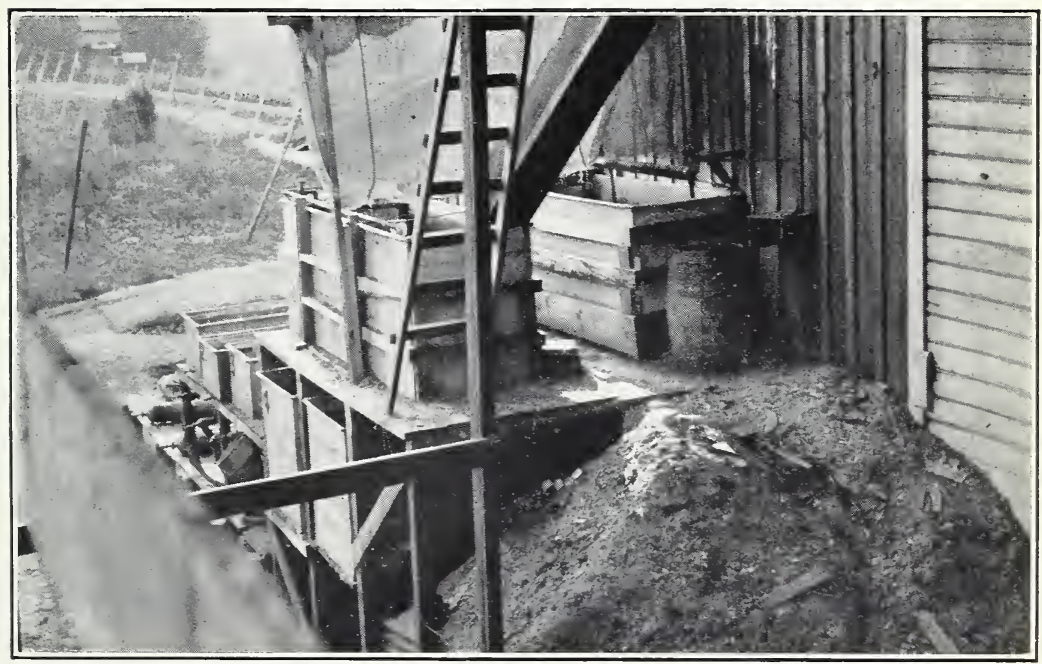

Fig. 2.-Boiling and mixing Plant Used at independence, Oreg. (Original.) FLOUR PASTE AGAINST THE HOP APHIS. 

THE USE OF QUASSIA.

Various formulas for quassia spray are used in the field and were observed to be effective when properly prepared. Some of them are as follows:

\section{Formula No. 1.}

Cents.

Quassia chips, 7 pounds, at $5 \frac{1}{4}$ cents per pound................... 37

Whale-oil soap, 9 pounds, at $4 \frac{1}{2}$ cents per pound . . . . . . . . . . . . . . 40.5

Water, 250 gallons. Total cost per 100 gallons.................... 31

\section{Formula No. 2}

Quassia chips, 8 pounds, at $5 \frac{1}{4}$ cents per pound.................... 42

Whale-oil soap, 6 pounds, at $4 \frac{1}{2}$ cents per pound..................... 27

Water, 100 gallons. Total cost per 100 gallons...................... 69

Formula No. 3.

Quassia chips, 9 pounds, at $5 \frac{1}{4}$ cents per pound.................. 47.2

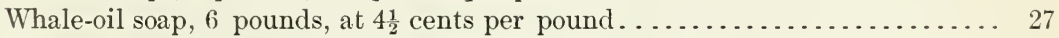

Water, 100 gallons. Total cost per 100 gallons..................... 74.2

Formula No. 1 was used by Prof. W. T. Clarke in his work upon the hop aphis at Watsonville, Cal., in 1902. It was also successfully used by the writer in some field experiments at Santa Rosa, Cal., during 1911. The other formulas are stronger and have also been observed to be effective when properly prepared.

\section{PREPARATION.}

Many failures in control work, when quassia is used, are due to faulty preparation of the material. Some growers only soak the chips and use what soaks out. Others boil them without previous soaking. The proper way to prepare quassia spray, based on Formula No. 1 , is as follows:

Soak the chips 24 hours, then boil for 2 hours in 3 gallons of water. Add this decoction to 247 gallons of water in which the soap has been dissolved. The whaleoil soap is readily dissolved by boiling in a small amount of water.

QUALITY OF QUASSIA.

The quality of quassia may vary and the percentage of quassin which can be extracted from the different grades of chips will not be the same. For this reason the use of quassia chips is not so certain in its results as a material containing a known amount of insecticide. When the quassia chips are used, it is well to look over sprayed areas three days after they are sprayed to be sure that the spray has been effective. 
QUASSIA EFFECTIVE ONLY BY CONTACT.

There is an erroneous impression among some growers that the quassia spray after it has dried upon the leaves will kill the aphides which later appear upon them. The quassia, as well as the other sprays used for the hop aphis, is effective only when in actual contact with the insects.

\section{EFFECT OF SPRAY MATERIALS UPON THE QUALITY OF SPRAYED HOPS.}

It was suggested by some growers that nicotine sulphate, whaleoil soap, and quassia extract might injure the quality of the hops on which they were applied. In order to test this point some nearly ripe hops were sprayed with the following materials, and when the crop was being picked these sprayed hops were picked, dried in the kiln with the other hops, and later sent to Washington for analysis:

Nicotine sulphate, 1-1,000; whale-oil soap. 4 pounds to 100 gallons.

Nicotine sulphate, 1-2,000; whale-oil soap, 8 pounds to 150 gallons.

Nicotine sulphate, 1-3,000; whale-oil soap, 4 pounds to 100 gallons.

Blackleaf tobacco extract, 1-60 and 1-75, each with 2 pounds of whale-oil soap to 100 gallons.

Quassia chips, $7 \frac{1}{2}$ pounds; whale-oil soap, 9 pounds to 250 gallons.

The following analyses were received from the Bureau of Chemistry:

TABLE VIII.-Analyses of hops sprayed with various insecticides.

\begin{tabular}{|c|c|c|}
\hline No. & $\begin{array}{l}\text { Whale-oil } \\
\text { soap. }\end{array}$ & Nicotine. \\
\hline $\begin{array}{l}1 \ldots \ldots \\
2 \ldots \ldots \\
3 \ldots \ldots \\
4 \ldots \ldots \\
5 \ldots \ldots \\
6 \ldots \ldots \\
\end{array}$ & $\begin{array}{l}\text { None. } \\
\text { None. } \\
\text { None. } \\
\text { None. } \\
\text { None. } \\
\text { None. }\end{array}$ & $\begin{array}{l}\text { None. } \\
\text { None. } \\
\text { None. } \\
\text { None. } \\
\text { None. } \\
\text { None. }\end{array}$ \\
\hline
\end{tabular}

The quassia was not tested for, as there is no test that is applicable.

From the above analyses it is evident that the nicotine or whale-oil soap that remained upon the hop cones was not present in sufficient quantities to be detected by a chemical analysis, and therefore would not injure the quality of the hops.

The flour paste is composed of starch and gluten, which has no distinct flavor or odor, and even through it were present in large amounts it can not be conceived how this material could influence the quality of the hops.

\section{DIRECTION IN WHICH TO WORK.}

Since the winged aphides travel largely with the wind, the best results will be obtained, especially where the winds are prevailingly from one direction, by working with the wind. If this is done the 
winged aphides will not be able to migrate to the sprayed hops so readily as if the wind were blowing from the unsprayed hopvines to those which have been spraved.

\section{CONTROL ON PRUNE.}

The hop aphis apparently is capable of migrating some distance, provided the wind is right, and in prune-growing sections it is impossible to kill all of the migratory insects. Where there are only a few prune or plum trees in the neighborhood, however, the destruction of any nonproductive trees and any wild plums that may be present will reduce the number of trees that will have to be sprayed.

The spraying of the plums and prunes can not be relied upon for the control of the hop aphis, but where it is thoroughly and systematically done the severity of the season's infestation may be greatly lessened. Work along this line is strongly recommended.

\section{FIELD OBSERVATIONS.}

About the time that the aphides are expected to appear upon the plum or hop it is advisable to go through the prune orchards or hopyards and note the conditions. Careful observations, if maintained throughout the season, will keep the grower informed as to the severity of the infestation in all parts of his hopyards. He will then be able to check the infestation before any serious damage has been done.

\section{SPRAYING REPORT.}

The following form of a daily report was successfully used by Mr. H. N. Ord at Independence, Oreg., in 1912, to keep a record of the spraying operations in the field:

\begin{tabular}{|c|c|c|c|c|c|c|c|c|}
\hline Date. & $\begin{array}{l}\text { No. acres } \\
\text { infested. }\end{array}$ & $\begin{array}{l}\text { No. acres } \\
\text { sprayed. }\end{array}$ & $\begin{array}{c}\text { No. gallons } \\
\text { used. }\end{array}$ & $\begin{array}{l}\text { Formula } \\
\text { and cost } \\
\text { per } 100 \\
\text { gallons. }\end{array}$ & $\begin{array}{c}\text { Effective- } \\
\text { ness of } \\
\text { spray ap- } \\
\text { plied three } \\
\text { days before. }\end{array}$ & $\begin{array}{c}\text { No. } \\
\text { machines } \\
\text { used. }\end{array}$ & $\begin{array}{l}\text { No. acres } \\
\text { sprayed per } \\
\text { machine. }\end{array}$ & $\begin{array}{c}\text { Cost of } \\
\text { operations } \\
\text { per acre. }\end{array}$ \\
\hline & & & & & & & & \\
\hline & & & & & & & & \\
\hline & & & & & & & & \\
\hline & & & & & & & & \\
\hline & & & & & & & & \\
\hline
\end{tabular}

If such a report is faithfully kept the grower will always know the condition of his hopyard and what his spraying operations are costing him.

SPRAYING MACHINERY.

Several forms of outfits may be successfully employed in the hopyards provided that they meet the following requirements: The machine should have a tank capacity of from 75 to 200 gallons, 
should supply at least two lines of hose at 120 to 150 pounds pressure, and should be in such order that there will be few breakdowns or delays. Good work can be done with the hand pumps (see Pl. VII, fig. 1), the gasoline power outfits (PI. VIII, figs. 1,2), the compressedair sprayers, etc., provided they meet these requirements and are supplemented by an efficient mixing and supply system.

The knapsack spraying machine (Pl. VII, fig. 2) may, under some circumstances, be of value for work on a very small scale, but is not at all practical in a commercial hopyard.

\section{BOILING AND MIXING PLANT.}

In designing a boiling and mixing plant for work on a large scale it is very desirable to arrange the tanks so that their filling and emptying is accomplished by gravity.

The uppermost tanks should be used for steeping the materials and should be supplied with water from a hydrant; the lower ones should be filled by drawing from the upper ones, or, when diluting is necessary, from a hydrant. The lower tanks, however, should be high enough to drain into a supply wagon.

DESCRIPTION OF TANKS.

The boiling and mixing tanks at Independence, Oreg., were made of No. 18 galvanized iron, riveted and soldered together, a $\frac{3}{4}$-inch iron pipe forming a brace for the tops. Three braces of $\frac{1}{4}$-inch angle iron, placed 3 feet 4 inches apart and riveted to the sides of the tanks, together with a framework of 2 by 4 planks, prevented the tanks from bulging.

ARRANGEMENT OF TANKS.

The arrangement of tanks shown in Plate VI, figure 2, was found very satisfactory. Two boiling tanks 10 by 3 by 3 feet 9 inches, heated by steam, were placed upon a 10 by 12 platform, elevated 10 feet from the ground. Passageways were left between and around the tanks. On a near-by but lower platform were three 375-gallon tanks for mixing and storage. A swinging outlet pipe drained the boiling tanks and directed the materials into any one of the three tanks. From the Jower tanks the material was run through a long hose into the supply wagons. In order thoroughly to strain the materials the entrances of all the outlet pipes were screened with wire gauze and the ends of the hose were covered with cheesecloth.

FIELD OPERATIONS.

SUPPLY WAGONS.

When extensive spraying operations are being carried on it is essential to have an adequate supply system. In an emergency a farm wagon containing barrels of spray (Pl. VIII, fig. 2) can be used, 


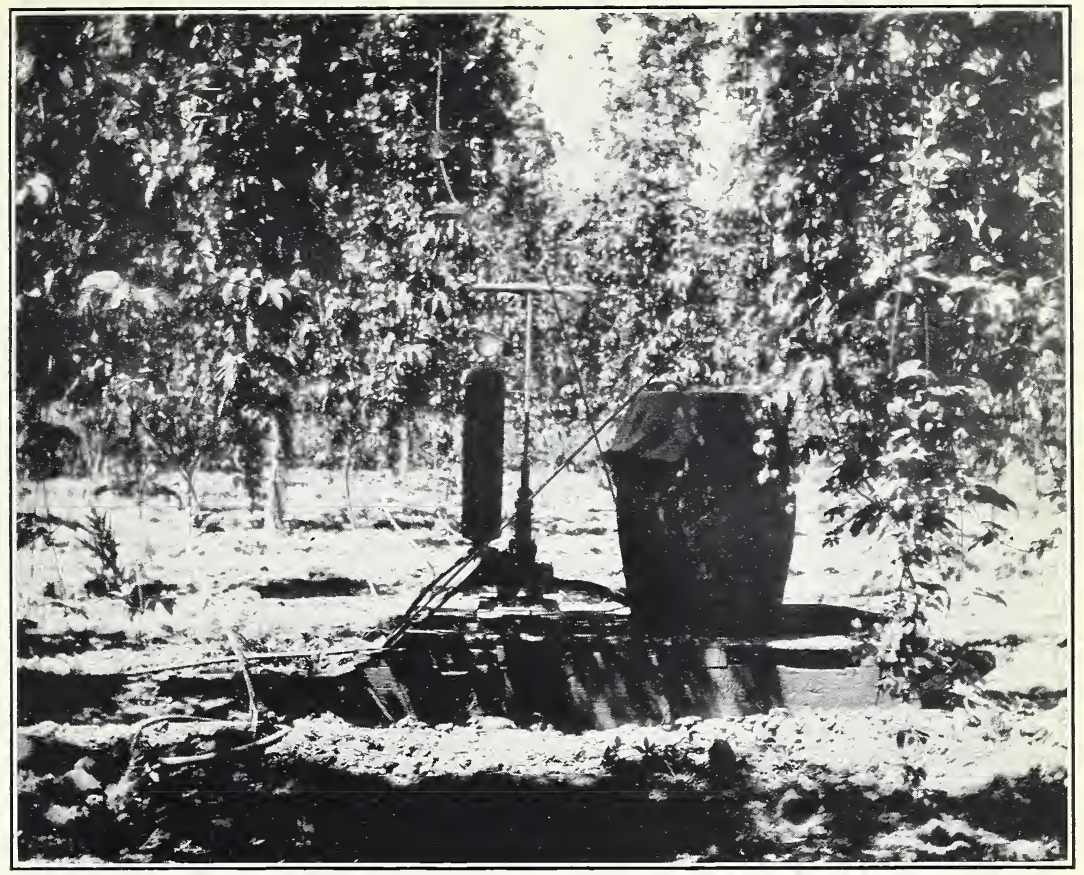

Fig. 1.-HANd Pump and Barrel on Sledge. (Original.)

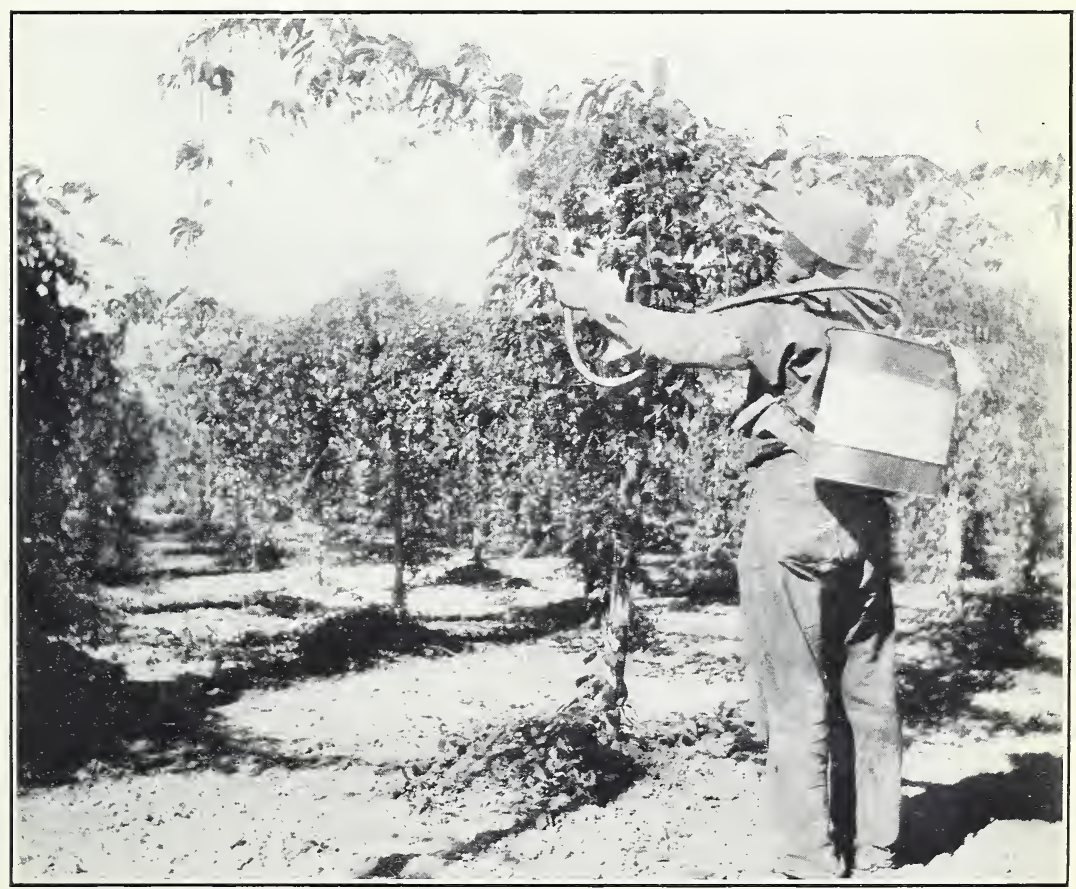

Fig. 2.-Knapsack Spraying Machine in USE IN Hopyard. (Original.) 


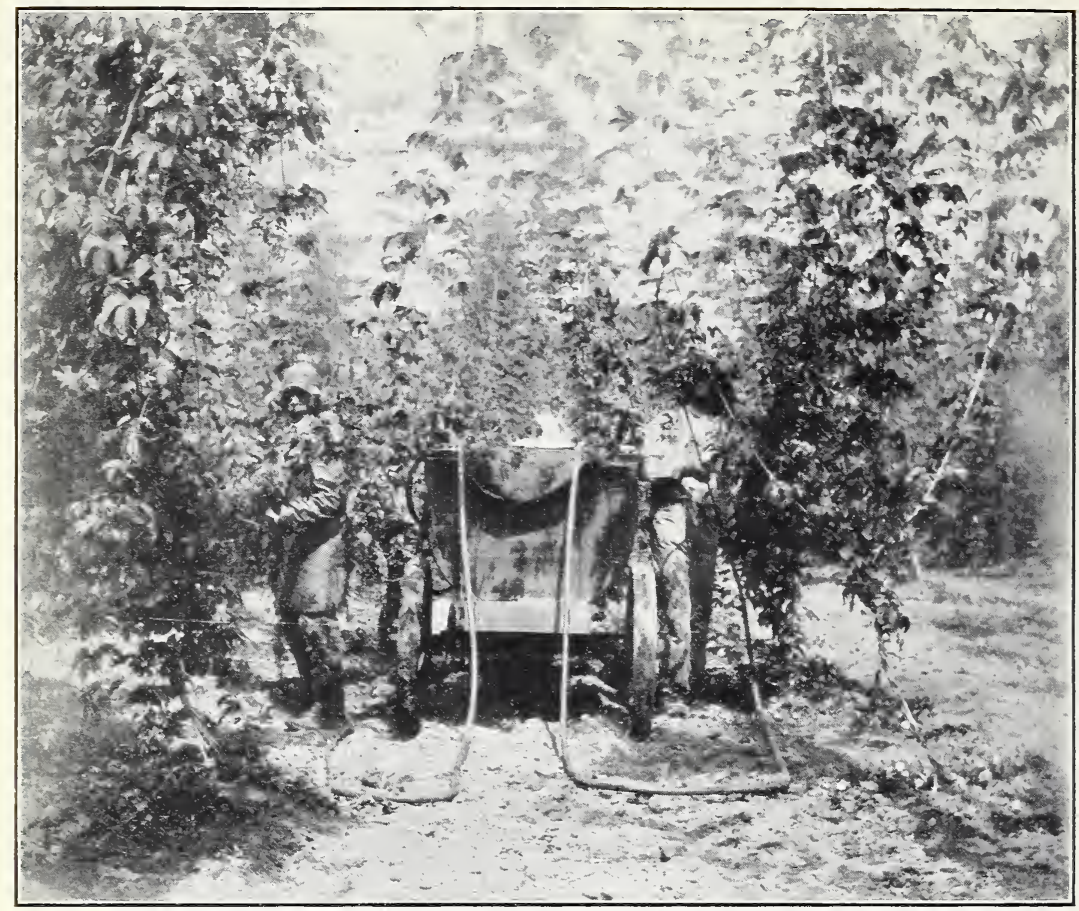

FIG. 1.-POWER OUTfit ON NARROW TRUCK, IN USE IN HOPYARd. (ORIGINAL.)

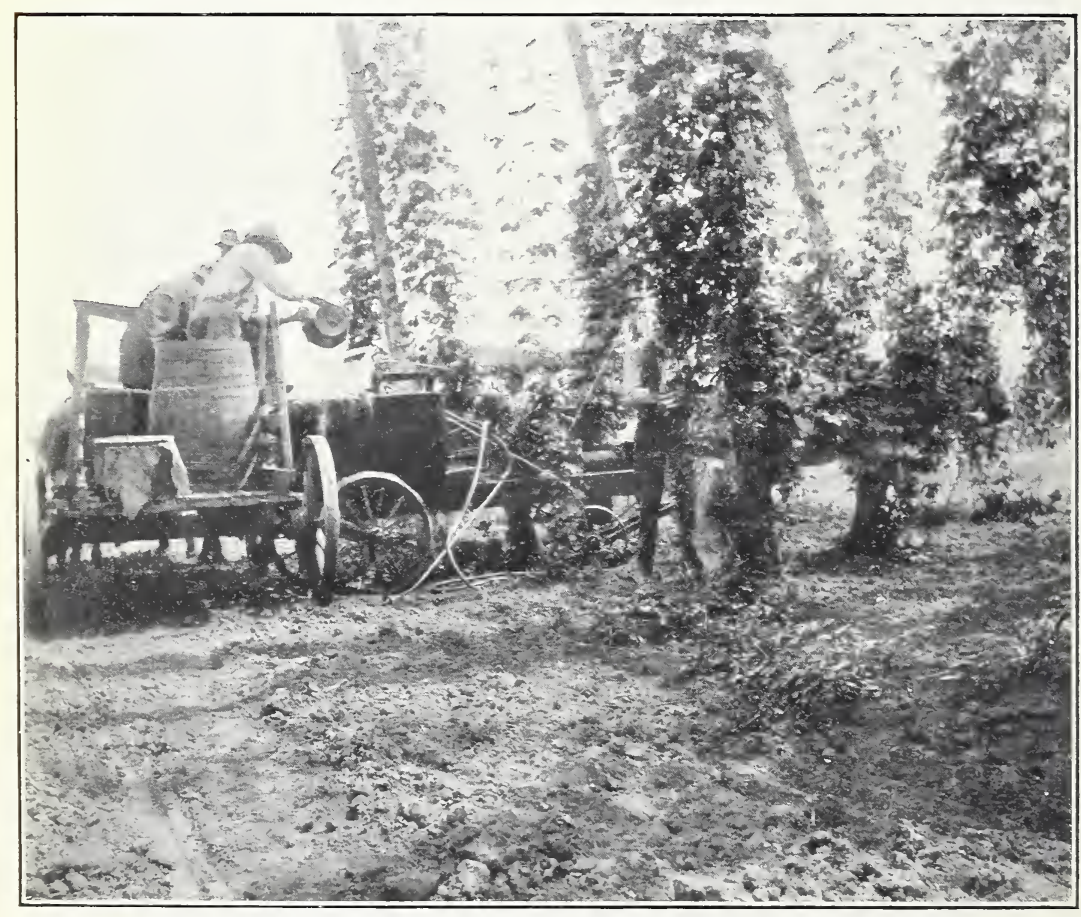

Fig. 2.-Filling Power Outfit from Improvised Supply Wagon. (Original.) 


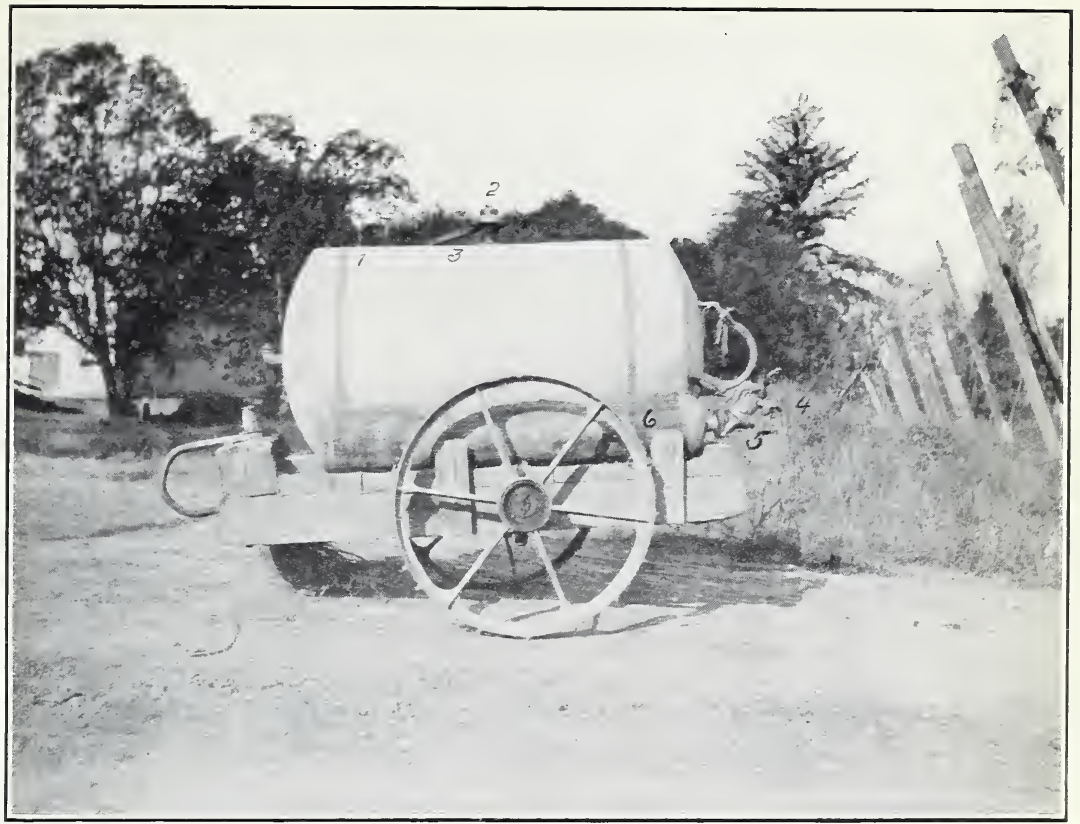

Fig. 1.-Compressed-Air Spraying Machine, Showing Air Bottle, Tank, Reducing Valve, and Pressure gauge. (Original.)

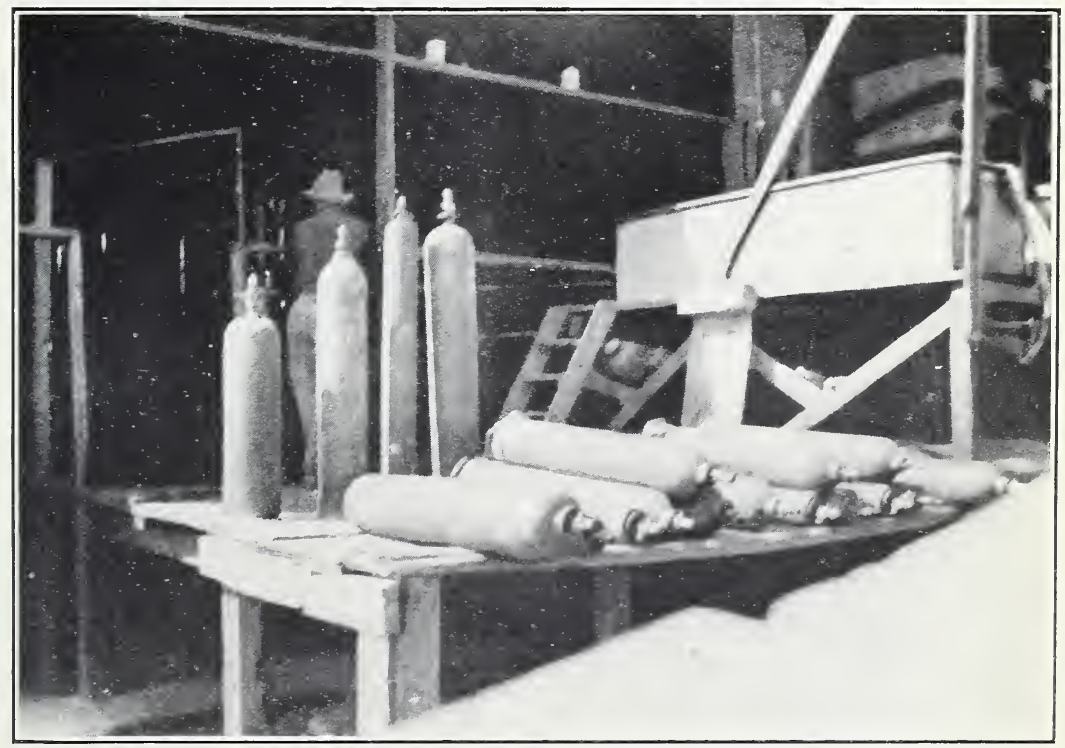

Fig. 2.-Filling Air Bottles for Compressed-Air Spraying Machine. (Original.) SPRAYING AGAINST THE HOP APHIS. 

but it is very desirable to have a large tank wagon made expressly for this purpose. When low spray tanks are used the spray can be run from the supply tank by gravity, but in most cases it is necessary to employ a good pump.

\section{EXCHANGE TANKS.}

When conducting spraying operations it is desirable to keep the entire force constantly employed. The use of an exchange tank is one of the best methods for accomplishing this purpose. An extra machine is filled after the other machines have started and is exchanged for the first one emptied. The exchange tank is driven down the row in which the nearly empty tank is working. When empty the men move back and take the exchange tank, the empty tank being then refilled and exchanged for the next empty tank.

SPRAY RODS.

When the hops are growing upon short poles the spray is most readily applied with a short spray rod. In the trellised yards, however, the hops are much taller and a 10-foot rod is necessary. The aphides are mostly upon the underside of the leaves, and in order to wash them thoroughly the spray must be directed from below. When angle nozzles are not available the spray rod may be bent so that the spray is readily directed to the underside of the leaves. If one or the other of these methods is not employed the material will not be satisfactorily applied.

\section{NOZZLES}

By exercising great care it was found possible to spray the hopvines thoroughly with a nozzle that produced a very fine mist spray. It was found much easier, however, to do the same work with a nozzle that produced a slightly coarser washing or driving spray. This type of spray is more satisfactory because by its driving force it turns the foliage and dashes over it. When cheap labor is employed good work is more readily obtained with the coarse driving spray than with the very fine mist spray.

\section{THE COMPRESSED-AIR SPRAYING MACHINE.}

The compressed-air spraying machine (Pl. IX, fig. 1), which is described below, was invented by Mr. Theodor Eder, of Perkins, Cal., who by the following statement has generously dedicated it to the use of the public. ${ }^{1}$

Whereas, I, Theodor Eder, of the town of Perkins, county of Sacramento, and State of California, having invented certain improvements in spraying devices for

\footnotetext{
1 A copy of this patent (No. 1046572) may be obtained for 5 cents by addressing the Commissioner of Patents, Washington, D. C.
} 
which I filed on the 20th day of March, 1909, an application for patent of the United States, serial No. 484784 ; and

Whereas, it is my desire that the public generally shall have the right to use said invention,

Now, therefore, I, the said Theodor Eder, hereby dedicate, grant and convey to the public at large and to whomsoever may desire to use said invention, the full right, liberty and license to make, use and sell apparatus embodying the said invention for the full end of the term of any letters patent which may be granted on said application.

And I hereby authorize and request the Commissioner of Patents to issue any letters patent which may be granted on said application to the people of the United States and Territories thereof as the assignee of my entire right, title, and interests in and to the same.

In witness whereof, I have hereunto set my hand and seal this 31st day of October, A. D. 1912 .

Theo. Eder.

This spraying machine (Pl. IX, fig. 1) is composed of a large iron tank, fitted with a pressure gauge (1), an inlet pipe with a strong screw cap (2) which is opened with a large wrench (3), an outlet pipe with cut-off $(4)$ and connected through a pressure-reducing ralre (j) with a large air bottle (6). (A large carbonic-acid gas bottle serves this purpose, the larger the better.) This machine is fastened onto a truck made from two old mower wheels and an iron shoe.

Provided that the spray material is thoroughly screened so that no dirt gets in to clog the nozzles, this machine is effective and is so small and light that it is readily hauled through a hopyard by one horse.

The air bottles are filled with air compressed by the air compress to 1,000 or 1,200 pounds (Pl. IX, fig. 2), loaded onto the supply wagon, and hauled with the spray to the field. The spray tank is filled, an air bottle connected with the reducing valve which has been set for 120 or more pounds pressure, the air is turned on, the pressure gauge indicates the pressure that is maintained, and the machine is ready for work.

The following information was received from Mr. Eder and gires data from which the cost of such a machine may be estimated:

Replying to your request in this regard, we beg to advise that the cost of these rigs depends upon the size of the spray tank, etc. A 150-gallon tank in black iron would cost about $\$ 12$. The reducing valves which we use between the air bottles and the tank cost $\$ 10$, including pressure gauges and fittings. Mowing machine wheels we buy old, costing from $\$ 1$ to $\$ 1.50$ per pair. The axles and other iron work on the truck cost in the neighborhood of $\$ 8$, and the woodwork, etc., would probably bring the entire truck construction up to $\$ 15$. The only things you would now have to add are spray hose, pipe, and nozzles, which expense would, of course, vary according to the number of leads and the length of same. We usually use four leads, two of 16 feet and two of 25 feet. We use seven-ply $\frac{1}{2}$-inch hose, costing about 12 cents per foot, and use 10 feet of $\frac{1}{4}$-inch pipe for spray rod to each lead, and a hop nozzle, which costs approximately 90 cents. The value of the pipe and valve would probably be $\$ 1$. The air bottles, if purchased in lots, cost \$12; singly, probably $\$ 15$.

For further information we beg to advise that a crew of four spray hands will empty a 250 -gallon spray tank on hops about five to six times a day, and this would require 
one full air bottle to each tank of spray. However, the same bottles are charged several times in a day, and on some ranches we run 10 or 12 spray rigs with three dozen bottles, and could probably get along with a few bottles less, if necessary.

The air compressor we use is a 10 by 12 double-acting mine compressor with the valves removed from one end. The piston rod is continued on through and the initial compressor puts the air through pipes immersed in water that cool same, and the ram at the other end of the piston rod puts this air up to 1,000 pounds. We use XX $\frac{3}{4}$-inch steel pipe for leads, and usually fill three or four bottles at a time, or new bottles can be put on and others taken off, without stopping the compressor. The compressor we have designed will charge about 25 bottles per hour, if necessary, all from 1,000 to 1,200 pounds. Lately we are charging quite a lot at 1,200 pounds, especially where we use 250 -gallon tanks. Cost of compressor, as fitted, $\$ 550$.

For small growers it would seem to us that they could club together and buy a compressor and bring their empty air bottles in for recharging, as a bottle gets away with a lot of spray even at high pressure. The reducing valves are so constructed that any pressure desired is obtained. We have also tried the use of carbonic-acid gas for spraying, but we use the spray material up so fast that the gas freezes itself up in the valve while coming out of the bottle when the pressure is being reduced. This could be overcome by the use of an alcohol lamp in the lead line, but this is too cumbersome; besides, air costs less.

\section{E. Clemens Horst Co., By Theo. Eder.}

\section{COST OF SPRAYING.}

The following estimate of the cost of spraying for the hop aphis is made from data taken from actual field work on high-trellis yards. The amount of material needed for hops on short poles will be somewhat less.

It has been found that one machine will spray from 2 to 3 acres per day, and that in order to do thorough work it is necessary to apply from 300 to 500 gallons per acre according to the amount of foliage on the vines. The following data are based upon a machine which will spray 2 acres per day:

Materials: Nicotine sulphate, 1-2,000; flour paste, 4-100. Cost, 70.8 cents per 100 gallons.

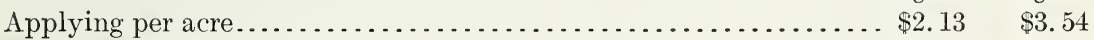

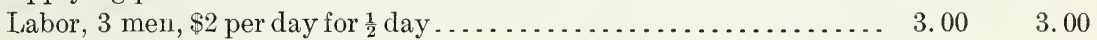

1 horse, 50 cents per day for $\frac{1}{2}$ day ............................. $\quad .25$

Total cost per acre of 1 application.................... $\overline{5.38} \quad \overline{6.79}$

Quassia and Whale-Oil Soap.-Formula No. 2.

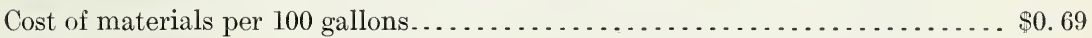

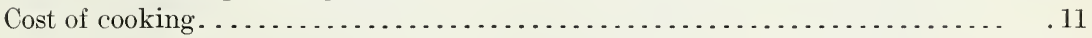

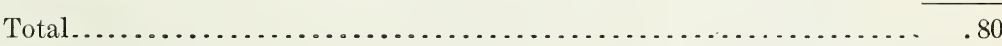

300 galls. 500 galls.

Applying per acre................................ \$2.40 \$4.00

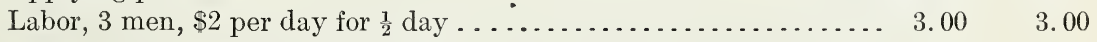

1 horse, 50 cents per day for $\frac{1}{2}$ day $\ldots \ldots \ldots \ldots \ldots \ldots \ldots \ldots \ldots \ldots \ldots \ldots \ldots \ldots .25 \quad .25$

Total cost of 1 application...................... $\overline{5.65} \quad \overline{7.25}$ 
The cost of stripping the vines preliminary to spraying will be from $\$ 1.80$ to $\$ 2$ per acre.

The cost of spraying for the hop aphis, although apparently great, is nothing compared to the losses which result from neglect to spray for this insect.

Thorough spraying is, then, a good business policy and should be carefully done by all commercial hop growers.

\section{CULTURAL METHODS.}

CLEAN CULTURE.

Suckers growing between the rows and vines growing over fences and near-by trees usually have much dense foliage, due to the growth

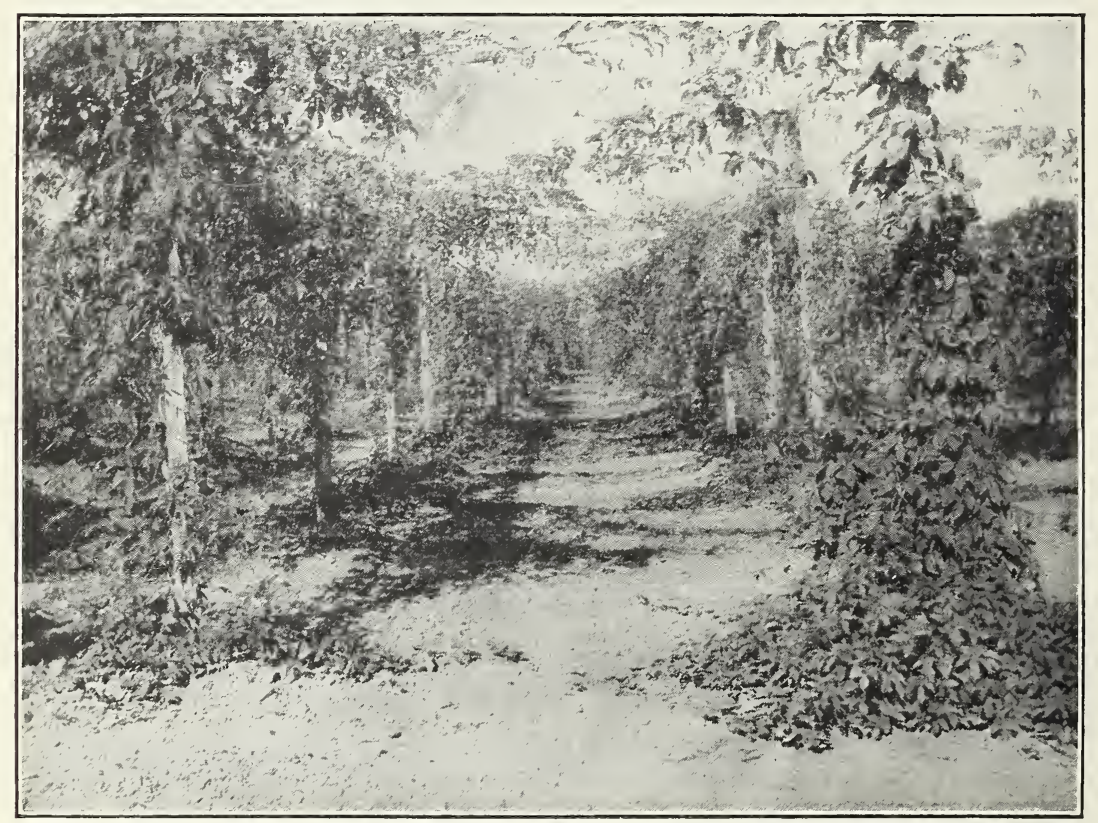

FIG. 8.-Short-pole hopyard, showing dense foliage around base of vines, which harbors the hop aphis. (Original.)

of several plants upon a limited area, and form an ideal breeding place for the aphides. Such plants may form a constant source of infestation and should be promptly removed.

STRIPPING THE VINES.

One of the most important cultural methods now in use is stripping the vines to a point about 4 feet above the ground (fig. 8). This removes the suckers and dense foliage, which protect and foster the aphides, from around the base of the vines. Experiments show that 


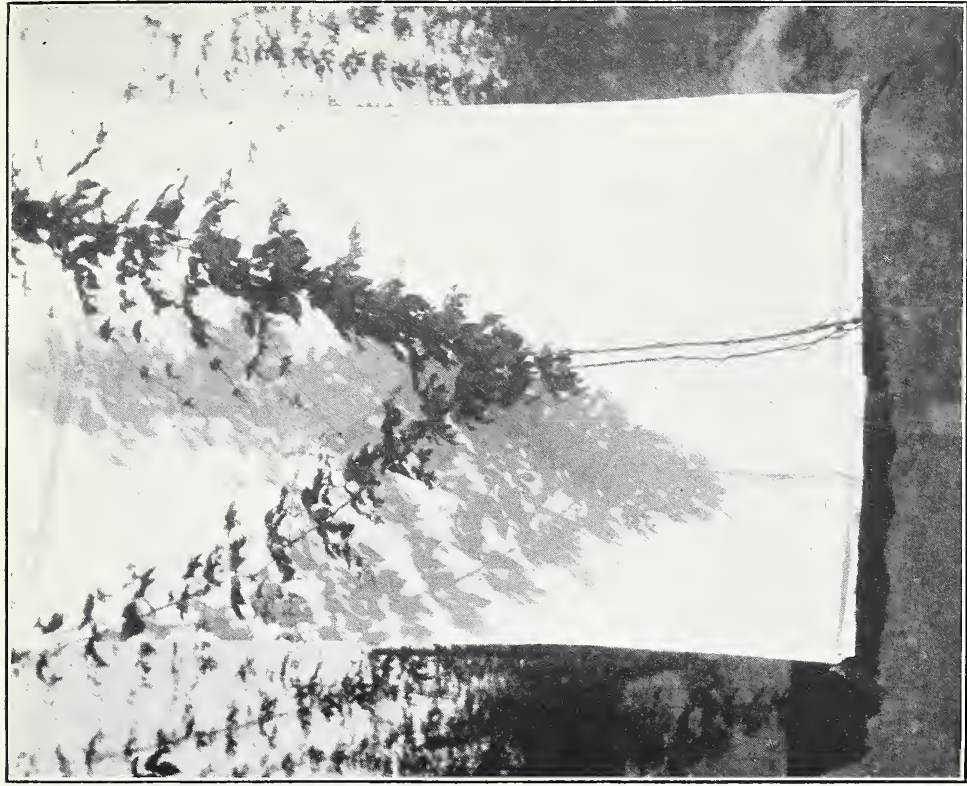

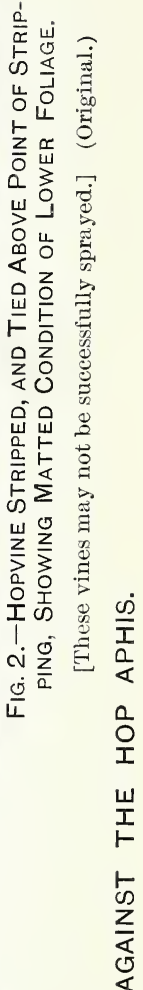

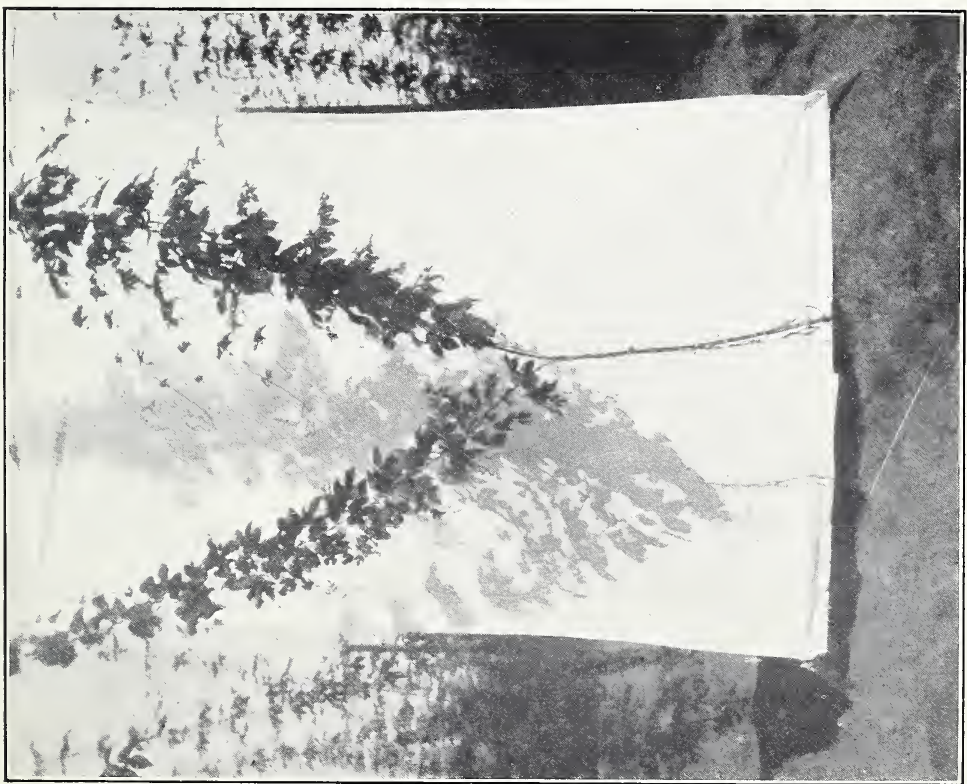

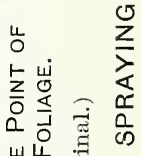

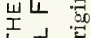

3 व

วิ

岹z

은

12

¿o

$\varangle$

岀

망 क

$\frac{0}{\alpha} \stackrel{0}{z}$

占窟

눌 중

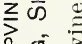

o 금

오릉 음

! 遂

$\because \frac{x}{\sim}$

बंक

나 
when the vines are stripped and tied together above the point of stripping ( $\mathrm{Pl}$. X, fig. 2) the foliage below this point is matted and difficult to spray thoroughly, but that when the vines are tied below the first foliage (Pl. X, fig. 1) the leaves are free and the undersides are readily treated. Stripping the vines is a necessary preliminary to the successful control of the hop aphis and should be done before commencing to spray.

\section{PICKING OFF INFESTED LEAVES.}

It is the custom of some growers to pick off the infested leaves and throw them on the ground. This practice reduces the infestation somewhat, but even though all of the removed aphides die, there are many scattered ones left upon the vines which will soon cause reinfestation. The writer has never observed any good results from this practice alone.

FERTILIZATION AND IRRIGATION.

Stimulation of the vines helps them to resist the draining effect of the aphides and encourages the production of the hops, but does not retard the insects in the least, the resulting dense foliage favoring their development. Proper irrigation and fertilization invigorate the hopvines and are very beneficial, but when an infestation occurs they should be supplemented by thorough spraying operations.

\section{GENERAL SUMMARY, WITH RECOMMENDATIONS.}

The investigation of the life history and control of the hop aphis has brought out the following points:

(1) The hop aphis, if not carefully controlled, always injures and may cause a total loss of a large portion of the crop.

(2) The insect may hibernate upon the plum or the hop. The destruction of the hibernating forms will aid in the control of this insect.

(3) The insect is readily killed by several contact insecticides.

(4) Several applications may be necessary to control an infestation successfully.

(5) If successful control is desired the spraying operations must not be delayed and the work must be very thorough; all of the leaves of the vines must be wetted on both sides. It is more economical to waste a little material than not to apply enough.

(6) Severe infestations have been successfully checked and clean hops obtained where the spraying operations were thorough. 


\section{THE MORE IMPORTANT WRITINGS ON THE HOP APHIS.}

1904. Clanke, W. T.-Bul. 160, Univ. Cal. Agr. Exp. Sta., 13 pp., 7 figs.

1897. Condley, A. B.-Bul. 45, Oreg. Agr. Exp. Sta., pp. 99, 127, 13 figs., June. Habits and remedies.

1903. Felt, E. P.-Proc. 24th Ann. Meet. Soc. Prom. Agr. Sci., pp. 39-48.

1865. Fiтch, A.-The Country Gentleman, vol. 25, p. 274, April 27. Destructiveness, enemies, and remedies.

1904. Fletcher, J.-Bul. 46, Div. Ent., U. S. Dept. Agr., pp. 82-88, May.

1904. Fletcher, J.-Rept. Exp. Farms Canada, pp. 163-215.

1887. Howard, L. O.-Country Gentleman, vol. 52, p. 875, November 17. First published full life history.

1897. Howard, L. O.-Bul. 7, n. s., Div. Ent., U. S. Dept. Agr., pp. 84-87.

1899. Howard, L. O.-Hop Industry, Orange Judd Co., New York, pp. 113-141, 19 figs.

Accounts of the species known to affect hops.

1893. Koebele, A.-Insect Life, vol. 6, pp. 12-17, November. Experiments with hop louse in Oregon and Washington.

1887. Lintner, J. A.-Cultivator and Country Gentleman, vol. 52, p. 511, June 30. Remedies.

1889. Lintner, J. A.-New England Homestead, p. 253, July 27. Remedies for hop aphis.

1891. Lintner, J. A.-New England Homestead, p. 193, May 2. How to control the hop aphis.

1900. Lugger, O.-Bul. 69, Minn. Agr. Exp. Sta., pp. 250, 200 figs., 16 pls.

1904. Pettit, R. H.-Spec. Bul. 24, Mich. Agr. Exp. Sta., pp. 79,70 figs.

1908. Rеміsсн, FR.-Zeitschrift für wissenshaftliche Insektenbiologie, vol. 4, no. 10, pp. 365-366. Important enemy of hops.

1910. Reмisch, Fr.-Zeitschrift für wissenshaftliche Insektenbiologie, vol. 6, no. 6, p. 242 .

Mentioned in article on Adalia bipunctata as the principal food of that species.

1911. RеміsсH, Fr.-Zeitschrift für wissenschaftliche Insektenbiologie, vol. 7, nos.

7-8, pp. 240-243; no. 9, pp. 282-285.

Article, "The hop leaf louse, A phis humuli."

1891. Riley, C. V.—Cir. 2, 2d ser., Div. Ent., U. S. Dept. Agr., pp. 7, 5 figs., 1 pl., June.

1891. Riley, C. V.-Insect Life, vol. 3, pp. 181-210, January.

1893. Riley, C. V.-Ann. Rept. U. S. Dept. Agr., pp. 199-226, 3 pls.

1891. Riley, C. V., and Howard, L. O.-Insect Life, vol. 3, p. 350, April.

1891. Riley, C. V., and How Ard, L. O.--Insect Life, vol. 3, p. 486, August. Hop lice on Pacific Coast.

1891. Riley, C. V., and Howard, L. O.-Insect Life, vol. 4, p. 84, October. Quassia for the hop aphis.

1892. Riley, C. V., and Howard, L. O.-Insect Life, vol. 4, pp. 342-343, June. Hop louse in the extreme northwest.

1892. Riley, C. V., and How ard, I. O.-Insect Life, vol. 4, p. 401, August. Hop aphis remedies.

1892. Riley, C. V., and Howard, L. O.-Insect Life, vol. 4, p. 406, August. The hop louse in Oregon.

1892. Riley, C. V., and Howard, I. O.-Insect Life, vol. 5, p. 60, September. The hop plant-louse in Washington.

1893. Riley, C. V., and Howard, L. O.--Insect Life, vol. 6, p. 53, November. Hop lice in New York State. 
1912. SAxpersor, E. D.-Insect Pests of Farm, Garden, and Orchard, pp. 27j-278, figs. 202-204.

On hop.

1891. Washblrx, F. L.-Bul. 10, Oreg. Agr. Exp. Sta., pp. 23-24, figs. 5. Description and treatment.

1893. Washburx, F. L.-Bul. 25, Oreg. Agr. Exp. Sta., pp. 9-12.

Treatment.

1894. Washburx, F. L.-Bul. 31, Oreg. Agr. Exp. Sta., pp. 79-8s, 3 figs., 2 pls., April.

1894. Washburx, F. L.-Bul. 31, Oreg. Agr. Exp. Sta., p. 82, April.

Brief notes, with suggestions as to remedies. 


\section{IN DEX.}

Page.

Adalia bipunctata, enemy of hop aphis........................ 23

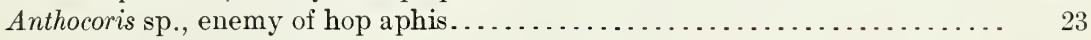

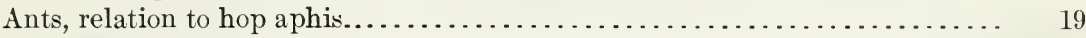

Aphides on shrubs and trees near hopyards mistaken for hop aphis........ 21

Aphis, hop, bibliography of more important writings . . . . . . . . . . . . . 38-39

control axioms..................................... 23

measures.................................... 23-37

on prune.................................... 31

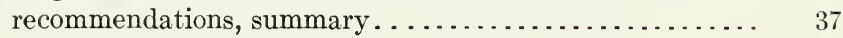

damage, nature................................. 21-22

deposition of young. . . . . . . . . . . . . . . . . .

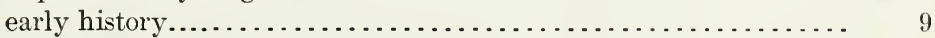

economic importance.............................. $9-10$

effect, general, upon hops........................ 21-22

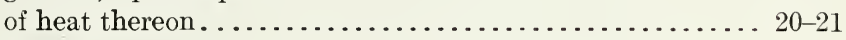

eggs, winter...................................... 17-18

emergence from hibernation........................... 12

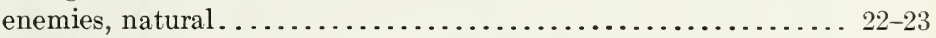

favorable and unfavorable conditions therefor............. 20-21

field observations, importance in control work............. 31

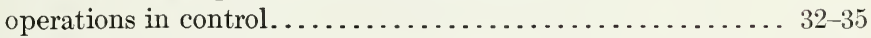

first appearance in season......................... 20

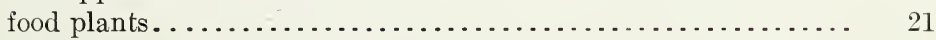

generations, number on host......................... 13

growth, rate.................................. $15-16$

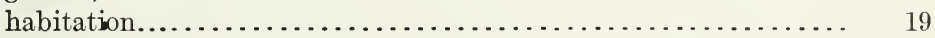

habits. ....................................... 19-20

head compared with that of melon aphis................ 15

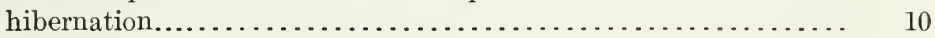

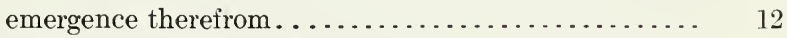

insecticides used in control......................... 23

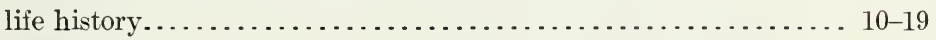

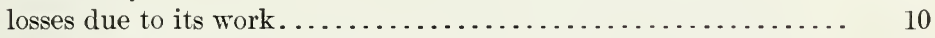

migrants, fall.......................................... 17

summer, theory regarding them................ 18-19

migratory activities. . . . . . . . . . . . . . . . . . . . . . . 13-14

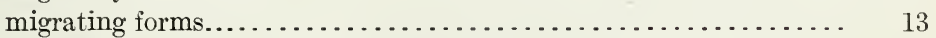

necessity for thorough work in control.................... 24

number of spray applications used in control.............. 24

young deposited by viviparous females........... 16-17

on hop roots................................. 10 12

procrastination in control work, results................... 24

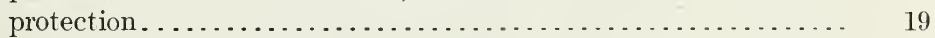

relation of ants thereto............................. 19 
A his, hop, reproduction,

$12-13$

spraying experiments in control...................... 24-27

time to begin............................ 23-24

summary, general................................. 37

young, number deposited by viviparous females.......... 16-17

melon, comparison of head with that of hop aphis............. 15

Aphis gossypii. (See Aphis, melon.)

Boiling and mixing plant for spraying against hop aphis............. 32

Camptobrochis nebulosus, enemy of hop aphis...................... 23

Chilocorus orbus, enemy of hop aphis........................... 22

Chrysopa californica, enemy of hop aphis.......................... 22

Cladosporium sp., blackening of hops caused thereby.................. 22

growing on honeydew excreted by hop aphides........ . 21-22

Clean culture against hop aphis................................ ${ }_{36}$

Coccinella abdominalis, enemy of hop aphis......................... 22

californica, enemy of hop aphis........................ 22

Compressed-air spraying machine, use against hop aphis, description....... 33-35

Cost of spraying against hop aphis............................... $35-36$

Cultural methods against hop aphis............................. 36-37

Direction in which to work in spraying against hop aphis............. 30-31

Fertilization in control of hop aphis..............................

Flour paste, advantages over whale-oil soap as a spreader for contact insecti-

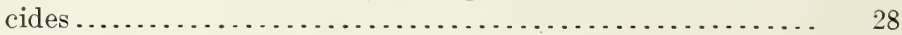

and nicotine sulphate against hop aphis ............... 26-27

cost per 100 gallons................ 35

effect on quality of hops ........................... 30

preparation ......................................... 27

Formica subsericea, relation to hop aphis......................... 19

Fungus, smut. (See Cladosporium sp.)

Heat, effect on hop aphis.................................... 20-21

Hippodamia convergens, enemy of hop aphis.................... 22

Honeydew excreted by hop aphis, black-smut.fungus (Cladosporium sp.) growing thereon......................... 21

effect on hops.................... 22

Hop aphis. (See Aphis, hop.)

picking off infested leaves for control of hop aphis..................

sometimes winter host plant of hop aphis...................... 14

vines, damage by black-smut fungus (Cladosporium sp.) growing on honey-

dew excreted by hop aphis......................... 21-22

stripping them in control of hop aphis................... 37

Hops, blackening caused by smut fungus, Cladosporium sp.............. 22

quality as affected by spray materials used against hop aphis........ 30

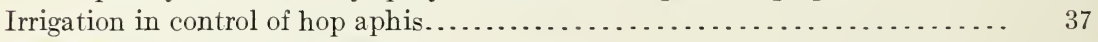

Lime sulphate ineffective against hop aphis. ................... 25

Machinery for spraying against hop aphis......................... 31-35

Nicotine solutions, mixing them with whale-oil soap............... 27

sulphate against hop aphis............................ 25-27

and cresol soap against hop aphis.................. 25

flour paste against hop.aphis................. 26-27

cost per 100 gallons.................. . 35

lye-resin soap against hop aphis............... 25

whale-oil soap against hop aphis............. 25-27 
Nozzles for spraying against hop aphis.

Phorodon humuli. (See Aphis, hop.)

Picking off infested leaves as remedy against hop aphis................

Picræna excelsa. (See Quassia.)

Plum, winter host plant of hop aphis............................ 14

Prune, winter host plant of hop aphis ....................... 14

Quassia against hop aphis.................................. 28 28

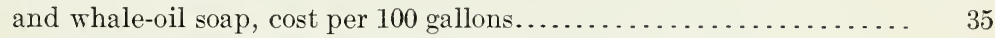

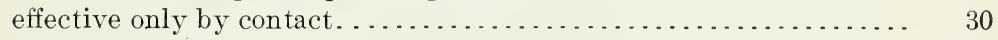

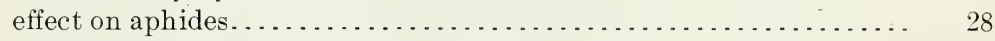

formulas............................................. 29

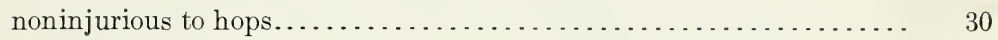

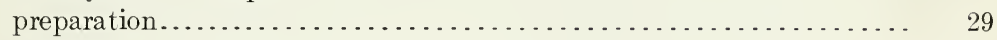

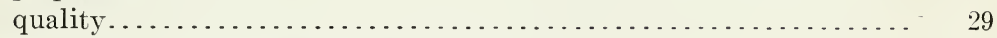

Report form for use in spraying against hop aphis. . . . . . . . . . . . $\quad 31$

Rods for spraying against hop aphis........................... 33

Sloe, winter host plant of hop aphis......................... 14

Soap, cresol, and nicotine sulphate against hop aphis .............. 25

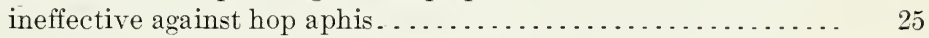

lye-resin, and nicotine sulphate against hop aphis............. 25

ineffective against hop aphis.................... 25

whale-oil, and nicotine sulphate against hop aphis............... 25-27

quassia, cost per 100 gallons..................... 35

mixing it with nicotine solutions................... 27

versus flour paste as a spreader for contact insecticides...... 28

Spraying against hop aphis, boiling and mixing plant................ 32

cost. . . . . . . . . . . . $35-36$

direction in which to work............... $30-31$

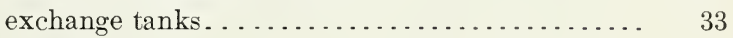

nozzles............................... 33

spraying machinery................... 31-35

report in daily use............... 31

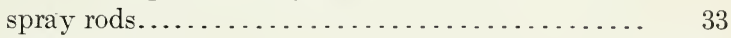

supply wagons......................... 32-33

tanks, arrangement..................... 32

description....................... 32

exchange........................ 33

Spraying machine, compressed-air, description and patent by Theo. Eder .... 33-35

Spray materials against hop aphis, effect on quality of hops............ 30

Stethorus punctum, enemy of hop aphis........................ 23

Supply wagons for spraying against hop aphis.................. $32-33$

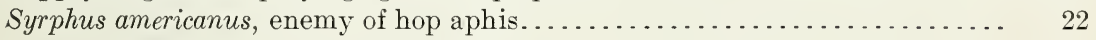

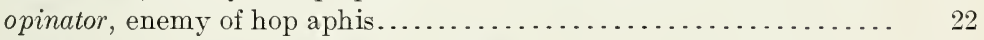

Tanks, exchange, for spraying against hop aphis................... 33

for spraying against hop aphis, arrangement, description.......... 32

Tobacco solution, blackleaf, against hop aphis . . . . . . . . 25

waste solution against hop aphis. . . . . . . . . . . . .

Triphleps insidiosus, enemy of hop aphis....................... 23

Weather. (See Heat.) 


